\title{
Trade preferences for developing countries
}

Thom Achterbosch

Frank van Tongeren

Sander de Bruin

Project code 62760

May 2003

Report 6.03.11

Agricultural Economics Research Institute (LEI), The Hague 
The Agricultural Economics Research Institute (LEI) is active in a wide array of research which can be classified into various domains. This report reflects research within the following domain:

\section{Statutory and service tasks}

Business development and competitive position

Natural resources and the environment

Land and economics

Chains

Policy

Institutions, people and perceptions

Models and data 
Trade preferences for developing countries

Achterbosch, T.J., S. de Bruin and F.W. van Tongeren

The Hague, Agricultural Economics Research Institute (LEI), 2003

Report 6.03.11; ISBN 90-5242-827-1; Price € 12.25 (including 6\% VAT)

53 p., fig., tab.

This report draws on a body of existing literature to assess the impact of trade preferences granted by the European Union on trade and welfare in developing countries. It is argued that the Everything But Arms amendment to the EU preference scheme will have limited effect on export potential and welfare in the least developed countries (LDCs). The EU would do well to simplify compliance with their rules of origin. When LDCs are granted deeper preferences under continued domestic agricultural policies in the EU, US, Canada and Japan, resources in LDCs will move towards the agricultural sector. The expected effect impact on LDCs of extending preferences to non-LDCs is quite small, while the negative effect of reductions of MFN tariffs under trade liberalisation is stronger.

Orders:

Phone: 31.70 .3358330

Fax: 31.70.3615624

E-mail: publicatie@lei.wag-ur.nl

Information:

Phone: 31.70 .3358330

Fax: 31.70.3615624

E-mail: informatie@lei.wag-ur.nl

(C) LEI, 2003

Reproduction of contents, either whole or in part:

$\square \quad$ permitted with due reference to the source not permitted

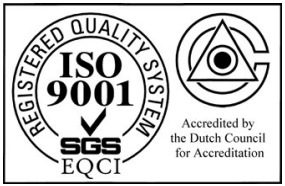

The General Conditions of the Agricultural Research Department apply to all our research commissions. These are registered with the Central Gelderland Chamber of Commerce in Arnhem. 


\section{Contents}

$\begin{array}{ll}\text { Preface } & 7\end{array}$

$\begin{array}{lr}\text { Summary } & 9\end{array}$

1. Introduction 11

2. The economics of preferential trade 12

$\begin{array}{lll}2.1 & \text { Welfare effects } & 12\end{array}$

2.2 Applied analysis: a comment about methods and outcome 14

3. History of preferential trade arrangements 15

4. EU trade preferences for agricultural products from developing countries 18

$\begin{array}{lll}4.1 & \text { Generalized System of Preferences (GSP) } & 18\end{array}$

$\begin{array}{ll}4.2 \text { The Cotonou Agreement } & 21\end{array}$

4.3 Everything But Arms 24

5. LDC exports to the EU before Everything But Arms 27

6. Estimated effects of preferences in agricultural trade 32

6.1 Trade perspective on preferential access to protected markets 32

6.2 Expected trade effects of EBA-like initiatives 33

$\begin{array}{ll}\text { 6.3 Trade effects of preference erosion } & 34\end{array}$

6.4 Economic development view on preferential access 36

$\begin{array}{ll}\text { 7. Conclusions } & 39\end{array}$

$\begin{array}{ll}\text { References } & 41\end{array}$

Appendices

1. Country list by tariff scheme $\quad 45$

2. EU market shares of country groups: LDC, Non-ACP LDC and ACP 48

3. Exports to EU from GSP countries, by product group 49

4. Analytics of trade preferences 


\section{Preface}

The 2001 Everything But Arms amendment and ongoing trade negotiations under the WTO Doha Development Round have further raised attention for issues of market access of products from the 'South' to the high-income markets of 'the Quad' (European Union, United States, Canada and Japan). This review report draws on a body of existing literature to assess the impact of trade preferences on trade and welfare in developing countries. This study is one in a series on agricultural trade policy and developing countries that LEI has prepared on behalf of the Dutch Ministry of Agriculture, Nature Management and Fisheries under the programme 404 (International Co-operation).

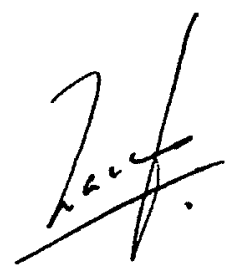

Prof. Dr. L.C. Zachariasse Director General LEI B.V. 


\section{Summary}

The 2001 Everything But Arms initiative and ongoing trade negotiations under the WTO Doha Development Round have further raised attention for issues of market access of products from the 'South' to the high-income markets of 'the Quad' (European Union, United States, Canada and Japan). This report provides an overview of the European schemes of trade preferences to low-income and middle-income countries. It draws on existing literature to address the following research questions: (i) What EU preference scheme applies to which country and to which product, and under what conditions? (ii) What incentives for global resource allocation follow from north-south preferential trade agreements for agricultural products, short-term and on the long run? What is the impact of preference erosion?

It is argued that the Everything But Arms (EBA) amendment to the EU preference scheme will have limited effect on export potential and welfare in the least developed countries (LDCs). Before EBA, almost 100 percent of LDC products were covered under alternative preference schemes, but utilisation of the preferences was quite low. As the amendment does little to simplify rules of origin and cumulation of value added, utilisation is not likely to rise. The EU would do well to simplify compliance with their rules of origin.

If all countries in the Quad remove tariff and non-tariff barriers to LDCs, these countries gain access to market segments in Quad that were effectively barred before. The weight of LDCs in global trade, is however too small for substantial producer losses in the Quad and other developing countries.

When LDCs are granted deeper preferences under continued domestic agricultural policies in the Quad, resources in LDCs will move towards the agricultural sector. The return to these short-term rents depends heavily on the investment spending of these rents. On the long run, the rents will decrease as domestic agricultural policies in the Quad are cut back, as MFN tariffs decrease under further trade liberalisation, and as zero-tariff preferences are extended to peer developing countries. The studies reviewed in this report agree that, for LDCs, the trade diverting impact of extending preferences to non-LDCs is quite small; the negative effect of MFN tariff reductions is stronger. If MFN tariffs and agricultural support in the Quad are reduced, it becomes necessary for LDCs that peer developing countries reduce tariff barriers too. 


\section{Introduction}

In 2001, the European Council granted, albeit with important exceptions, unrestricted access at zero tariff duty of products from least developed countries (LDCs) to the EU market. Trade negotiations under the WTO Doha Development Round have further raised attention for issues of market access of products from the 'South' to the high-income markets of 'the Quad' (European Union, United States, Canada and Japan). This report provides an overview of the European schemes of trade preferences to low-income and middle-income countries. The research questions to be addressed are:

- developing and least developed countries' share of agricultural imports into EU is governed by the Generalised System of Preferences, the Cotonou Agreement, and the Everything But Arms amendment to the GSP scheme. What scheme applies to which country and to which product, and under what conditions?

- what incentives for global resource allocation follow from north-south preferential trade agreements for agricultural products, short-term and on the long run? What is the impact of preference erosion in case of ongoing multilateral tariff reduction? Should we expect benefits or costs from trade creation and trade diversion?

The report is organised as follows: Chapter 2 provides a basic introduction to the economics of preferential trade. Chapter 3 provides a brief historic overview of trade preferences, from the early years of GATT to the schemes that were introduced in the last couple of years. Chapter 4 discusses in detail three main preferential trade arrangements that govern developing countries' exports to the EU. Chapter 5 analyses potential trade gains for the least developed countries from the EBA initiative by matching data on trade preferences with LDC market shares in EU trade. Chapter 6 analyses the simulation results in three recent studies from the World Bank and UNCTAD on the effects of trade preferences for world trade and welfare. Also, it provides a summary on the impact of EBA. Chapter 7 concludes. Various boxes feature examples on discussions in the main text. 


\section{The economics of preferential trade}

This chapter provides a basic introduction to the economics of preferential trade. Below the concepts of trade creation and trade diversion are introduced, terms often used to describe the impact of preferences on trade and welfare. When trade preferences are granted to a selection of (potential) foreign producers, there is a primary impact on trade flows in the preferred good, a secondary impact on substitutes and complements, and a tertiary impact following readjustment of the balance of payments (Pomfret, 1997, p.183). The discussion in this report is confined to the primary and secondary impact. Following the theoretical discussion, the chapter closes with a note on applied analysis.

\subsection{Welfare effects}

Imagine a world consisting of just three countries in which just a single good is produced and consumed. Country A imports that good and charges the same tariff, whether the products originate from country B or country C. It just so happens that production of the good is more costly in country B than in country $\mathrm{C}$, so that the producers in $\mathrm{C}$ can offer the good to the consumers in A at a price below that of country B producers. Initially, then, country A imports products only from country C. If country A now decides to grant trade preferences to either country B or C - that is, to reduce the tariffs for products more from the one country than for the other - several trade effects may occur. The effects on trade flows in the goods concerned can be summarised in the notions of created and diverted trade.

- Trade creation occurs when reduced tariffs or quota encourage trade, allowing imports to displace less efficient local production and/or to expand consumption (McCulloch et al., 2001). In terms of our 3-country example: trade creation occurs when following a tariff reduction for products from low-cost producer $\mathrm{C}$, consumers in country A substitute local products for those from country C. The more pricesensitive is import demand, the more impact preferential trade has on country A.

- $\quad$ Trade diversion occurs when a trade reform discriminates between different trading partners and results in a higher cost source displacing a lower cost source (McCulloch et al., 2001). In terms of the trade between countries A, B and C: trade diversion occurs when goods from country B are charged a lower tariff than goods from country $\mathrm{C}$, resulting in the replacement of imports from $\mathrm{C}$ by imports from country B. Then, the preference to country B implies an incentive for inefficient production patterns in the world.

In the scenario where goods from high-cost producer $\mathrm{B}$ receive trade preferences over those from low-cost producer $\mathrm{C}$ on the market of country $\mathrm{A}$, the welfare effects are composed of changes in: 
- $\quad$ producer surplus in (high-cost) country B (PSb);

- $\quad$ consumer surplus in importing country (CSa);

- $\quad$ producer surplus in importing country (PSa);

- $\quad$ tariff revenue in importing country (tariff payments for exporting country) (TRa);

- $\quad$ producer surplus in the (low-cost) country C (PSc).

See Appendix D for a graphical demonstration; here, these effects are clarified along the lines of a basic equation. Suppose that preferential access increases imports from the beneficiary country at the expense of domestic products. Then, the basic welfare impact of preferential trade to the world (W) is:

$$
\mathrm{W}=\Delta \mathrm{CSa}-\Delta \mathrm{TRa}-\Delta \mathrm{PSa}+\Delta \mathrm{PSb}+\Delta \mathrm{PSc}
$$

In the beneficiary countries, welfare increases from the arrangement: exporters save tariff duties and perhaps increase the volume of exports at prices possibly well-above world market prices, $\Delta \mathrm{PSb}>0 .{ }^{1}$ The welfare effect for the importing country is ambiguous. The importing country will lose tariff revenue as imports from the beneficiary country enter at reduced or zero tariff rates. There is trade creation; so domestic producers will lose from the arrangement and their surplus, $\triangle \mathrm{PSa}<0$. Consumers gain from lower prices, hence consumer surplus increases, $\Delta \mathrm{CSa}>0$. In sum, tariff revenues decrease, producers loose part of their rents to producers elsewhere, and consumers benefit from lower sales prices. The net result depends on whether consumer gains from the price reduction make up for the producer and revenue losses.

Equation 1 includes producer effects in 'third' country C, PSc. Imports from the favoured country may displace imports from third countries and reduce producer surplus in country $\mathrm{C}(\triangle \mathrm{PSc}<0)$. In terms of global welfare, the impact relates to the global allocation of resources: consumers may end up buying the less efficiently produced good of the two. This inefficiency is crucial to the trade diversion effect, which is a major welfare caveat to discriminatory trade relations, as it implies a loss of global welfare and consumer surplus.

While the beneficiary country will definitely gain from the trade diverting arrangement, the third country certainly looses, and the total effect on the importing country is uncertain. Hence, total impact on world welfare is ambiguous. ${ }^{2}$ A full assessment of the impact of the Everything But Arms (EBA) initiative on world welfare should include trade and welfare effects of all countries. Due to the minor share of the LDC trade in world trade, producer losses due to displaced trade in the EU and in non-LDC developing countries are likely to be small in general.

\footnotetext{
${ }^{1}$ The rents accrue to producers in the exporting country that receives the preference, unless they are somehow taxed. Ways for Governments in beneficiary countries to capture some of these rents include export tax and a system of export licenses.

${ }^{2}$ One relevant interpretation of equation 2 is that governments in developed countries choose to support the exporting sector in selected developing countries, in which sense trade preferences may be compared with other instruments for development assistance. Whether this practice is global welfare enhancing or not cannot be stated in advance. See Topp (2001) and Tangermann (2001) for a discussion.
} 


\subsection{Applied analysis: a comment about methods and outcome}

The results from applied analysis are quite sensitive to the extent to which products of alternative origin (i.e. produced in the importing or 'donor' country, the beneficiary country or a third country) can substitute each other in trade. For a great deal of products, consumers are not indifferent to the origin of the product, so that a product made in the one country is not a perfect substitute to a similar product made in the other country. The more easily products substitute each other in global markets, the stronger effects the introduction of trade preferences will have. Empirical studies emphasise - by assumption - either that products from favoured countries easily displace domestic products, or that favoured countries will replace third country products in the market. In general equilibrium models, such as those used by Bora et al. (2002), Ianchovichina et al. (2000) and Kerkelä et al. (2000), estimates of trade diversion pivot around Armington substitution elasticities and the sectoral composition of exports. Moreover, impact analysis by general equilibrium models, with their emphasis on factor costs and terms of trade effects, generally yield stronger trade diversion and weaker trade creation effects than analyses in a partial equilibrium setting, for example the model used by Hoekman et al. (2001). See chapter 6 for a discussion of empirical results. 


\title{
3. History of preferential trade arrangements
}

\author{
The period 1950-2000
}

For decades, preferential access to developed countries has been an important part of international trade and development policies. ${ }^{1}$ Even during the early days of the General Agreement on Tariffs and Trade (GATT, since 1995 continued in the WTO), trade preferences were widely accepted. Under the GATT regulation, trade preferences had to be nondiscriminatory, i.e. it was not allowed for imports from some countries to receive larger preferences than others. That would undercut one of the cornerstones of GATT; that each member receives preferences similar to that of the nation most favoured before GATT. Hence Most Favoured Nation (MFN) tariffs became normal GATT tariffs. In the late '50s, early '60s the European Community undermined the principle of non-discrimination. In the Rome Treaty, it is stated that (former) colonies of European Community states should have duty-free access to the entire Community market. Although this was clearly an act of discrimination towards other trading partners, the Community took the position that these agreements were non-negotiable. The United States did not object to the agreements, and GATT adopted them. In the Kennedy Round (1965) discriminatory policies were allowed, but only if they concerned trade preferences for less-developed countries.

In the early 1970s most developed countries, including the European Community, designed a Generalized System of Preferences (GSP). The general idea of these GSP schemes was to promote export and industrialisation in developing countries, by granting them preferential access to the internal markets of developed countries. Today, the GSP scheme of the European Union comprises of 179 countries, which receive some trade preferences.

Next to the GSP scheme, the European Community designed discriminatory preferential trading schemes for a sub-set of GSP countries. In 1975, it signed the Lomé Convention with a set of 77 African, Caribbean and Pacific (ACP) countries. 'Lomé' meant to enhance and narrow down trade preferences: it covered more product groups; trade preferences were 'deeper', i.e. preference margins were larger than under GSP; and it generally focused on the less developed countries and former colonies. These countries were granted further reduced tariffs or even duty free access on numerous export products. At first glance the Lomé Convention seemed to offer much to the ACP countries. However, for several reasons the system was not that generous. First, most tariff reductions were concentrated on products with a low initial tariff and products that were not exported by most ACP-countries. Second, the arrangement excluded most agricultural products covered by the Common Agricultural Policy (CAP). Sugar might be considered an exception to this, as 17 ACP countries (plus India) were granted special quota for sugar under the Special Pref-

\footnotetext{
${ }^{1}$ See Pomfret (1997) for a more elaborate historical overview.
} 
erential Sugar arrangement. This arrangement has been of great value to the few participating ACP-countries, which include four Least Developed Countries. Third, although manufacturing products received larger preference margins, they were restricted by several costly rules, such as the rules of origin. These imply that the base material for some products should be local and that there should be 50-60\% local value added. Furthermore, the product had to undergo two stages of production in the ACP-country. Since most ACP countries were hardly industrialised it was virtually impossible for them to comply with these rules. Fourth, tariffs on processed products, such as canned fish, were much higher than the tariffs on the unprocessed product, i.e. raw fish. A tariff structure like this, also known as tariff escalation, obviously, does not promote industrialisation. See Box 1 for an example of such a tariff structure for cacao. Fifth, the European Community restricted the volume of trade that could benefit from reduces tariffs by introducing tariff rate quotas on nearly all products. Tariff rate quotas (TRQs) imply a two-tiered tariff: an in-quota tariff (the lower tariff) combined with a volume constraint, and an out-quota tariff (the higher tariff) that applies for all trade that exceeds the volume restriction. These TRQs effectively limited the increase in exports from ACP countries.

It is obvious that the limited range of agricultural products covered by the preference schemes, the strict value-added requirements, the quantity restrictions and tariff escalation schemes did not support the initial objectives of export promotion and industrialisation.

\section{The period 2000-2003}

The Lomé Convention was reviewed at the end of the 1990s and replaced by the Cotonou Agreement in 2000. Most of the differences are of a political nature, e.g. more emphasis on good governance, democratic principles, human rights and social development. In order to boost economic performance the Cotonou Agreement focuses even more on (regional) development projects, such as infrastructure. Furthermore, special funds from the EU to promote social and economic development are subjected to less rigid allocation systems, i.e. they can be adapted to the specific institutional context of the beneficiary country. Trade policies, however, are hardly affected by the Cotonou Agreement.

For the group of least developed countries (LDCs), the EU has specific preference schemes in place that are technically part of the GSP scheme. In March 2001, the GSP LDC scheme was replaced by the well-received Everything But Arms (EBA) initiative. The EBA initiative grants 49 of the Least Developed Countries duty-free access to the EUmarket for all products, except arms. Also, EBA slightly changes the conditions on rules of origin for LDCs. Initially three 'sensitive' products are excluded from EBA: bananas, rice and sugar. Tariff rates for these products will gradually be reduced and abolished by 2006 (bananas) and 2009 (rice and sugar).

Although the EBA initiative is highly praised by the international community, the question rises how much the EBA initiative will bring to the LDCs over the substantial preferences under GSP and ACP. In the following, it is argued that EBA does little to solve important constraints for LDC exports to the EU that currently prevail. 
Cacao is one of several sectors faced with a tariff escalation scheme. Cacao and cacao preparations are an important export product for developing countries, for some of vital importance even. For example Indonesia is the third exporter of cacao beans in the world (see Appendix C, table c), making it one of its most important agricultural export products. ${ }^{1}$

Although tariff lines and regulations for cacao are relatively simple and clear cut, the EU tariff structure of cacao is a perfect example of tariff escalation. As already mentioned in the text, tariff escalation refers to a tariff structure with increasing tariff rates as the stage of processing increases. Table 1 shows the tariff structure for cacao and cacao related products. To products from Indonesia, GSP rates apply. The scheme clearly shows that Indonesia's preference margin on the MFN rate decreases with the stage of processing.

Table $1 \quad$ Tariff rates under the GSP scheme of the EU

\begin{tabular}{lrcr}
\hline 1999-2001 in \% & MFN rate & GSP preference margin & GSP rate \\
\hline Cacao beans & 3 & 100 & 0 \\
Cacao powder & 16 & 85 & 5,6 \\
Cacao paste, etc. & 15 & 30 & 10,5 \\
Chocolate, etc. $>2 \mathrm{~kg}$ & 22,3 & 30 & 15,6 \\
Chocolate, etc. $<2 \mathrm{~kg}$ & 10 & 15 & 8,5 \\
\hline
\end{tabular}

Note: Data are calculated from the AMAD database.

Nearly half of all cacao beans exported by developing countries go to the European Union, yet a mere 4.913 tonnes of chocolate products from these countries were shipped to the EU in 1996 (the EU itself produced over 3 million tonnes ${ }^{1}$ ). One reason for the distorted trade relation between the EU and cacao exporting countries is the tariff structure as presented above.

The tariff escalation forces developing countries to produce cacao preparations at much lower cost than the EU in order to be competitive with EU producers. Producing at such low costs is almost impossible for developing countries, hence, investing in processing industries is hardly profitable. The result of the tariff escalation on cacao products is that investment in the processing industries is low, hampering development of these industries. The EU tariff scheme on cocoa is an impediment to development of cocoa processing activities in Indonesia.

Box 3.1 Tariff escalation case: cacao

${ }^{1}$ Source: Trade and Environment Database. 


\section{EU trade preferences for agricultural products from developing countries}

In the previous section, several preferential trade arrangements have been briefly addressed. This section discusses in more detail the most important agreements regarding trade between the European Union (EU) and developing countries: the Generalized System of Preferences, the Cotonou Agreement and the Everything But Arms initiative. The discussion of the schemes follows a similar structure by addressing the objective; the tariff scheme; the impact of the scheme on seasonal duties; and safeguards and reasons for exclusion and rules of origin.

\subsection{Generalised System of Preferences (GSP)}

\section{Objective}

The objective of the GSP scheme as formulated by the EU is as follows:

The Community's common commercial policy must be consistent with and consolidate the objectives of development policy, in particular the eradication of poverty and the promotion of sustainable development in the developing countries. (European Commission, 2001b)

All countries classified as developing countries are eligible to preferential access for their products to the EU market. ${ }^{1}$ The arrangement affects several major trade partners of the EU such Argentina, Brazil, China, India, Indonesia, Malaysia, Philippines, Russian Federation, Taiwan, Thailand and Ukraine. The Generalised System of Preferences grants preference margins according to the level of protection on the internal market: on sensitive products MFN-tariffs are reduced by 3.5\%, non-sensitive products receive $100 \%$ preference margin. GSP preferences account for all goods, but several agricultural goods are excluded. Moreover, a large number of bilateral agreements between EU and GSP partners undercut the GSP scheme. The latest GSP regulation extends the programme to 2004, and includes the Everything But Arms initiative for LDCs.

\section{Tariff scheme}

In the GSP scheme most products are charged a combination of two tariff types. Tariff cuts are granted on imported products that originate from GSP countries. The actual tariff cut

\footnotetext{
${ }^{1}$ The European Union follows the World Bank classification.
} 
(i.e. the preference margin) depends on a classification of products into sensitive and nonsensitive products. ${ }^{1}$ The main elements of the 2002-2004 GSP scheme are:

- $\quad$ for non-sensitive products, duties are completely suspended;

- $\quad$ for sensitive products, ad-valorem tariffs are cut by 3.5 percentage points, while specific tariffs should be reduced by $30 \%$;

- $\quad$ several agricultural products in the non-sensitive category do not benefit from the $100 \%$ preference margin.

There are several more exceptions to the general scheme. First, if the previous GSP scheme grants a higher preference than the current scheme, the previous preference margins continue to apply after January 1st 2002. Second, exceptions apply to specific products. For example, according to the AMAD database, ethyl alcohol has the specific tariff cut by $15 \%$. Third, some countries are excluded for selected fishing products and iron and steel products. ${ }^{2}$ Although there are more exceptions, they do not apply to agricultural products. In the GSP scheme, quite a lot of agricultural products do not receive any preferential trading; these are levied the higher MFN tariffs. On average, the EU GSP programme reduces trade barriers by half (Hoekman et al., 2001, p.10).

\section{Seasonal duties}

Most countries pose seasonal duties in order to protect domestic producers against lower priced foreign products during the harvest and selling period. Although little is mentioned in the EU preferential regulations, the EU does pose seasonal duties on several products originating from GSP countries. According to the AMAD database, 22 horticultural and fruit products face an import duty during a given part of the year. ${ }^{3}$ During these periods advalorem duties of around $20 \%$ and specific duties of well over a 100 ECU per tonne are not uncommon. For instance, grapes face an ad-valorem duty of $22 \%$ and a specific duty of 120 ECU per tonne from July 21 to October 31 . See box 4.1 for an example on apples. Seasonal duties are not mentioned in preference schemes; hence these tariffs apply to all exporting countries, with the positive exception of the EBA beneficiaries, who are granted complete duty free access.

\section{Safeguards and exclusion from GSP}

In order to protect its own producers a safeguard is adopted in the GSP regulation, which is the same as the GATT safeguard. The GSP tariff scheme can be suspended if the imports

\footnotetext{
1 Before 2001, GSP schemes distinguished between four categories of sensitivity: non-sensitive, semisensitive, sensitive and very sensitive. The latest scheme, for the years 2002 to 2004, mentions only two. It is unclear whether the categories semi-sensitive and very sensitive continue to be applied.

${ }^{2}$ These countries are Armenia, Azerbaijan, Belarus, China, Georgia, Greenland, Kyrgyzstan, Kazakhstan, Moldova, Russia, Tajikistan, Turkmenistan, Ukraine, Uzbekistan and South Africa.

${ }^{3}$ Vegetables: Cucumbers, Potatoes, Tomatoes, Cauliflowers, Cabbage lettuce, Celeriac, Peas, Beans, Artichokes. Fruits: Avocados, Oranges, Mandarins, Grapefruit, Grapes, Apples, Apricots, Cherries, Pears, Peaches, Plums, Strawberries, Kiwifruit. Tariff data obtained from the AMAD database.
} 
from certain countries 'cause or threaten to cause serious difficulties to a Community Producer'.

Next to the safeguard, the EU has adopted several rules to suspend preferential arrangements for some or all products originating in a beneficiary country, in case of:

- $\quad$ the use of slavery, forced or child labour;

- $\quad$ serious and systematic violation of the freedom of association, the right to collective bargaining or the principle of non-discrimination in respect of employment and occupation;

- $\quad$ export of goods made by prison labour;

- failure of custom controls on export or transit of drugs and/or practices of money laundering in the beneficiary country;

- $\quad$ fraud, irregularities or failure to comply with the rules of origin of products and/or the proof thereof;

- $\quad$ unfair trading practices;

- $\quad$ contravention of the rules concerning the conservation and management of fishery resources;

- a country exceeding a certain level of development;

- $\quad$ a sector exceeding a certain level of development.

Breaking one of these rules may result in the reinstatement of the MFN tariffs for all or certain products originating in the beneficiary country.

\section{Rules of Origin}

The rules of origin are to determine whether a product or a certain part thereof is manufactured in the beneficiary country or not. It prevents third countries from using the beneficiary country as a transit in order to obtain the reduced import tariff. The most important part of these rules is that processed products should have undergone sufficient processing in the beneficiary country. Manufactured goods are particularly affected by these rules of origin, but agricultural (processed) products face rules as well.

On unprocessed agricultural products, rules of origin concern whether a product is wholly obtained, whether it contains certain inputs or whether certain inputs make up a certain part of the price. Base products or materials, such as live animals, meat and trees, should be wholly obtained in the GSP country. Still, there are rules about whether a product is wholly obtained in a country or not, especially with fish and fish related products. Rules of origin related to fishery practices are quite elaborate and appear difficult and costly to prove.

Processed products are subject to other, more complicated, rules. Virtually every agricultural commodity that has undergone some processing is subjected to rules of origin. Some products should/shouldn't or may/may not contain certain inputs, e.g. the manufacture of bakers' ware (bread, biscuits, etc.) may not include imported inputs from chapter 11 (products of the milling industry incl. flour). In this case, the beneficiary country should make all wheat, flour and bread. Another requirement states that several imported inputs may be used in the processing of an agricultural commodity provided that the input costs do not make up more than a certain share $(30$ or $70 \%)$ of the price. 
The EU poses tariffs on apples year throughout the year. Because they differ considerably by season, these tariffs are considered to be seasonal duties. Table 2 presents these seasonal duties. EU customs not only levy the seasonal duty, but also enforce a minimum entry price for selected horticultural products. The entry price gives the minimum price under which products are allowed to enter the EU. On top of this a custom tariff and a maximum tariff equivalent (MTE) are posed. The height of the MTE changes with the height of the import price. Lower import prices, generally means a higher MTE (MTEs given in the table are maxima). Most seasonal duties for fruit and vegetables are constructed this way. As can be seen, total levy on outside-EU prices can amount to over $50 \%$ ad valorem.

Table 2 EU entry price and customs tariffs in 2000 for apples

\begin{tabular}{lccc}
\hline Period & $\begin{array}{c}\text { Entry price } \\
\text { (euro/tonne) }\end{array}$ & $\begin{array}{c}\text { Tariff rate } \\
(\% \text { ad valorem })\end{array}$ & $\begin{array}{c}\text { MTE } \\
\text { (euro/tonne) }\end{array}$ \\
\hline $01 / 08-31 / 12$ & 457 & 9,0 & 238 \\
$01 / 01-31 / 03$ & 568 & 4,0 & 238 \\
$01 / 04-30 / 06$ & 568 & 3,0 & 238 \\
$01 / 07-31 / 07$ & 457 & 3,0 & 238 \\
\hline
\end{tabular}

Source: Van Berkum et al. (2002).

Box $4.1 \quad$ Seasonal duties case: apples

\subsection{The Cotonou Agreement}

\section{Objective}

The Cotonou Agreement between the members of the African, Caribbean and Pacific Group of States (ACP) and the EU should promote

'(...) the economic, social and cultural development of the ACP States, contributing to peace and security and promoting a stable and democratic political environment.' (European Commission, 2000b) 
Under the Cotonou Arrangement, successor to the 1975 Lomé Convention, over 70 countries are granted preferential access to the EU market for selected goods. ${ }^{1}$ Over USD 8 billion worth of agricultural goods were exported from ACP countries to the EU in 2000.

As can be seen from the objective, the Cotonou Agreement goes much further than a normal preferential trading scheme. The agreement not only promotes the export and production sectors in the beneficiary countries it also supports the non-private sector, cultural activities and political (democratic) stability. Achieving this goal is not merely done by financial support, but also by knowledge transfers to ensure a stable socio-economic and democratic environment. In short it is much more an agreement aiming for overall development, than for trading preferences alone.

\section{Tariff scheme}

The tariff scheme under Cotonou is a myriad of preferences specific to countries and products. These are best described in relation to the GSP scheme. Since the Lomé Convention was signed in 1975, the EU has granted most ACP countries 'deeper' and 'wider' trade preferences than under the GSP scheme. That is, for ACP countries, tariff cuts are larger and apply to a broader selection of products. Under the current Cotonou Agreement, most advalorem tariffs are suspended and some specific tariffs have been lowered compared to GSP. Cotonou also covers more agricultural products than GSP, and can be said to actually increase access of agricultural products from beneficiary countries to the EU market.

\section{Seasonal duties}

The Cotonou Agreement makes no mention of any form of seasonal duties. However, seasonal duties applied under the GSP scheme apply likewise to ACP countries. These could be a serious impediment to horticultural and fruit exports from the ACP region.

\footnotetext{
177 ACP countries are covered under the Cotonou Agreement, the following 76 are eligible for ACP trade preferences: Angola, Antigua and Barbuda, Bahamas, Barbados, Belize, Benin, Botswana, Burkina Faso, Burundi, Cameroon, Cape Verde, Central African Republic, Chad, Comoros, Congo (Brazzaville), Congo (Kinshasa), Cook Islands, Côte d'Ivoire, Djibouti, Dominica, Dominican Republic, Equatorial Guinea, Eritrea, Ethiopia, Fiji, Gabon, Gambia, Ghana, Grenada, Guinea, Guinea-Bissau, Guyana, Haiti, Jamaica, Kenya, Kiribati, Lesotho, Liberia, Madagascar, Malawi, Mali, Marshall Islands, Mauritania, Mauritius, Federal States of Micronesia, Mozambique, Namibia, Nauru, Niger, Nigeria, Niue, Palau, Papua New Guinea, Rwanda, Saint Kitts and Nevis, Saint Lucia, Saint Vincent and the Grenadines, Samoa, Sao Tome and Principe, Senegal, Seychelles, Sierra Leone, Solomon Islands, Somalia, Sudan, Suriname, Swaziland, Tanzania, Togo, Tonga, Trinidad and Tobago, Tuvalu, Uganda, Vanuatu, Zambia, Zimbabwe. South Africa and Cuba are also ACP members. However, Cuba is no signatory to the Cotonou Agreement and South Africa has already concluded a Trade and Development Co-operation Agreement (TDCA) with the EU.
} 
Although not explicitly mentioned in the former Lomé Convention or the Cotonou Agreement, there are some Tariff Rate Quotas (TRQs) in the preferential trading agreement. For these tariff lines, there is an in-quota tariff and an out-of-quota tariff. ${ }^{1}$

Preference schemes offered by EU to non-LDC developing countries often fail to address high MFN tariff barriers on products of importance to their trade potential. To see this, we analyse here the impact of the GSP and Cotonou preference scheme on 'peak tariffs' in the EU scheme. Tariff peaks refer to MFN tariff lines above $15 \%$ ad valorem. In the US and Canada over $85 \%$ of tariff peaks is in industrial products (mainly clothing and textile), agricultural products account for $91 \%$ of tariff peaks in EU and $77 \%$ in Japan.

EU tariff peaks are summarised in table 4.1, drawn from Hoekman et al. (2001). It shows the peak MFN tariff and the prevailing preference margins for various categories (HS classification, 6-digit level) of EU imports subject to tariff duties of $15 \%$ and more. Note that the leftmost column provides product categories at the HS2 level, whereas the other columns refer only to the number of tariff lines ('products definition') at HS6 level.

The table illustrates several issues. First, MFN agricultural tariffs in the EU are quite high on average. Where MFN tariffs are high, preference margins are generally low. Therefore, preferences offer little protection against tariff peaks. Second, preferences for ACP countries are substantially more generous than the GSP scheme. GSP preferences are not too generous except for coffee and tea, tobacco and footwear. ACP countries 'compete' for the best preference. Third, ACP and GSP do not address heavy protection by tariff peaks for meat, cereals and dairy and, to a lesser extent, sugar.

Box 4.2

EU tariff peaks under GSP and Cotonou

\section{Safeguards and exclusion from Cotonou}

The rules for suspension of (a part of) the preferential agreements are the same as for the GSP scheme, with one exception: preferences are not conditional on the level of development in a beneficiary country or sector.

\footnotetext{
${ }^{1}$ Most analytical studies cite a calculated tariff, after weighing in-quota and out-quota rates by the value of in-quota and out-quota trade.
} 
Table 4.1 Selected EU tariff peaks by country group and product

\begin{tabular}{|c|c|c|c|c|c|}
\hline \multirow[t]{2}{*}{ Tariff Peak at HS 2-digit Products } & \multirow{2}{*}{$\begin{array}{l}\text { Coverage } \\
\text { \# of 6-digit } \\
\text { tariff-lines }\end{array}$} & \multirow{2}{*}{$\begin{array}{l}\text { MFN tariff } \\
(\%)\end{array}$} & \multicolumn{3}{|c|}{ Preference margin (ratio) } \\
\hline & & & GSP & $\mathrm{ACP}$ & LDC \\
\hline 01 Live animals & 7 & 38.2 & 0.00 & 0.30 & 0.06 \\
\hline 02 Meat and edible meat offal & 41 & 71.0 & 0.00 & 0.10 & 0.08 \\
\hline 03 Fish \& crustacean, mollusk nes & 17 & 18.7 & 0.10 & 1.00 & 1.00 \\
\hline 04 Dairy prod; birds' eggs; honey & 25 & 59.1 & 0.01 & 0.06 & 0.12 \\
\hline 06 Live tree \& other plant; bulb, flowers & 2 & 16.9 & 0.18 & 1.00 & 1.00 \\
\hline 07 Edible vegetables and roots \& tubers & 12 & 25.4 & 0.15 & 0.66 & 0.79 \\
\hline 08 Edible fruit and nuts; melons & 8 & 20.2 & 0.12 & 0.64 & 0.66 \\
\hline 09 Coffee, tea, mat and spices & 2 & 16.0 & 0.69 & 1.00 & 0.50 \\
\hline 10 Cereals & 14 & 75.6 & 0.00 & 0.06 & 0.06 \\
\hline 11 Prod mill indust; malt; starches & 31 & 38.2 & 0.02 & 0.20 & 0.17 \\
\hline 12 Oil seed, oleagi fruits; misc grain & 1 & 74.4 & 0.00 & 0.16 & 0.15 \\
\hline 13 Lac; gums, resins \& other veg & 1 & 17.8 & 0.30 & 1.00 & 1.00 \\
\hline $15 \mathrm{Animal} / \mathrm{veg}$ fats \& oils \& prod & 8 & 56.0 & 0.19 & 0.51 & 0.60 \\
\hline 16 Prep of meat, fish or mollusks & 22 & 23.5 & 0.20 & 0.67 & 0.68 \\
\hline 17 Sugars and sugar confectionery & 9 & 37.6 & 0.03 & 0.21 & 0.14 \\
\hline 18 Cocoa and cocoa preparations & 1 & 24.0 & 0.10 & 0.25 & 0.25 \\
\hline 19 Prep of cereal, flour, starch/milk prod & 13 & 34.1 & 0.11 & 0.39 & 0.37 \\
\hline 20 Prep of vegetable, fruit, nuts prod & 42 & 26.1 & 0.15 & 0.88 & 0.88 \\
\hline 21 Miscellaneous edible preparations & 8 & 19.2 & 0.28 & 0.78 & 0.95 \\
\hline 22 Beverages, spirits and vinegar & 12 & 35.7 & 0.33 & 0.77 & 0.71 \\
\hline 23 Residues \& waste from food indust & 6 & 71.4 & 0.03 & 0.11 & 0.06 \\
\hline 24 Tobacco and manufactured & 8 & 56.2 & 0.39 & 1.00 & 1.00 \\
\hline
\end{tabular}

Reproduced from Hoekman, $\mathrm{Ng}$ and Olarreaga, 2001, table A2. Notes:

For the first three columns from the right, values presented are preference margins on the MFN tariff rate, i.e. a value of 1.00 implies 100 percent margin (zero duty), a value of 0.00 implies full MFN duty rate.

All specific tariffs have been converted into ad valorem tariffs.

GSP preferences reflect the 1999-2001 scheme (European Commission, 1998).

ACP countries preferences are derived from the agreements of the Lomé IV Convention, not the Cotonou Agreement.

\subsection{Everything But Arms}

\section{Objective}

The European Council decided to grant the least developed countries (LDCs) additional trade preferences 'in the light of the real risk of the LDCs becoming increasingly marginalised in the world economy' (European Commission, 2001a). The initiative was formalised as an amendment to the GSP scheme of the EU, which entered into force by March 2001. Over USD 2.6 billion worth of agricultural goods were exported from LDC countries to the EU in 2000. 


\section{Tariff scheme}

As mentioned earlier, the everything But Arms (EBA) initiative grants duty-free access for all products except arms and ammunition to 49 of the world's poorest countries (see Appendix 1 for a list of countries). Three important agricultural products remain under protective rules access: bananas, rice and sugar. The tariffs on these products will gradually be reduced and completely abolished by 2009 in accordance with the following scheme:

- $\quad$ Bananas: 20\% annual reduction from January 2002 and complete liberalisation from 2006. On January 2002, EU specific import tariff on bananas was 544 euro per 100 $\mathrm{kg}$ for LDCs and 680 euro per $100 \mathrm{~kg}$ for other countries of origin (Bora et al. 2002);

- Sugar: the liberalisation scheme implies a full phaseout of tariffs and quotas for sugar imports of LDC origin by 2009. Market access is increased in four steps, each to take place on July 1 , resulting in $20 \%$ tariff reduction in $2006,50 \%$ reduction in $2007,80 \%$ reduction in 2008 and full liberalisation on 1 July 2009. The effective EU import tariff (specific tariffs excluded) on sugar in 1998 differed between 75 and 103 percent for all countries of origin (Bora et al., 2002);

- Rice: market access for rice imports will be increased along a scheme similar to sugar, also leading up to full liberalisation by July 2009. The effective EU import tariff (specific tariffs excluded) on paddy rice in 1998 was 61\% for LDCs and 65\% for all other countries of origin; processed rice imports were levied a $87 \%$ effective tariff, irrespective of origin (Bora et al., 2002).

\section{Seasonal duties}

For LDC exporters, seasonal duties are waived.

\section{Non-tariff barriers}

Since all products eventually receive duty free access, there are no tariff rate quotas for LDC exports after 2009. Tariff rate quotas (TRQs) for bananas will remain effective until 2006, TRQs for rice and sugar until 2009. These TRQs consist of a duty free contingent and a tariff for exports that exceed the quota. The contingent consists of a certain volume based upon the export volumes of recent years; every consecutive year the quota will be increased by fifteen percent.

\section{Safeguards and exclusion from EBA}

Since the Everything But Arms initiative is an extension of the GSP agreement, safeguards and rules for exclusion of the EBA are basically the same as for the GSP scheme. No country or sector has been excluded from the EBA or GSP, except Myanmar, for its serious and systematic violation of the Universal Human Rights. Myanmar can therefore only apply to the Most Favoured Nation (MFN) tariff. 


\section{Rules of Origin}

The basic rules of origin under GSP have been adapted slightly under EBA. The most important change is the 'full cumulation system', which is aimed to provide an opening for LDCs to become an intermediary producer and exporter on the global market. Under this system, LDCs may process and re-export at zero-tariff products imported from the ASEAN, SAARC and EU region. The full cumulation condition is that the processing in the LDC adds $100 \%$ value to the product. That is a deviation from previous rules, which states that two stages of processing have to occur in the LDC itself. Rules of origin remain, however, complex obstacles to LDCs.

Up to now we have discussed several preferential tariff schemes: GSP, Cotonou and EBA. Although it might seem that these schemes are very transparent and easy to find, they certainly are not. Several schemes overlap one another or other (bilateral) agreements, which means that you have to find out which country is subjected to which regulation for which product. Furthermore, most schemes are subject to continuous reforms: the GSP scheme of the EU is a point in case. The GSP scheme was developed in the early 70's and ever since, it has been adapted, reviewed and changed, with every modification referring to previous resolutions. Next to these general regulations, most schemes have exceptions for certain products or countries, which are being described in separate resolutions. These ongoing changes and exceptions make it quite difficult to find the right tariff preference and rules of origin for a certain product.

The listing of products need some studying as well, because all products are listed by their $\mathrm{CN}$ code, provided that the regulation has a product list. Hence, it is necessary to read these listings, which can be over 100 pages long, with a $\mathrm{CN}$ code list next to it.

The previous GSP scheme, which was valid from 1998 to 2001, had a categorisation of products into four groups: very-sensitive, sensitive, semi-sensitive and non-sensitive. Products were categorised and listed by $\mathrm{CN}$ code in an annex of the regulation (no. 2820/98). The latest revision of the GSP scheme (no. 2501/2001), which came into action January 1st 2002, consists of only two sensitivity categories (sensitive and non-sensitive). Although this resolution comes with a listing of products, it is very unclear whether it consists of just these two categories. EU and non-EU articles still refer to the categorisation of the prior regulation. Furthermore, the list is considerably shorter which means that quite a lot of products are all of a sudden not covered by the GSP scheme (e.g. hams and alike).

The next step is to find out what the height of the tariff is, since the regulations merely determine the (ad-valorem) preferences. The EU does not list or mention the cur-rent (applied) rates. In order to find those rates one has to use other resources, such as AMAD or UNCTAD databases.

Which brings us to the next problem: different databases report different rates over different years, making it difficult to determine whether the tariff rate is still applicable. To make it even more complicated, they also present preferences on specific tariffs and on quota, although the EU regulations merely discuss ad valorem preferences.

So far we have only discussed tariff preferences and tariff rates, however, the rules of origin are an important part of every preference scheme as well. The general rules of origin can be found in the legal text of the specific regulation, at least for GSP, regulations for Cotonou are virtually impossible to find and EBA is an adaptation to the GSP scheme, which means that most rules of origin are mentioned in the GSP regulation. More detailed (product specific) rules are listed, by $\mathrm{CN}$ code, in the Community Customs Code (regulation no. 1602/2000), covering over 70 pages.

As can be seen, the determination of a tariff rate, a tariff preference and whether a product meets the requirements of the rules of origin, is a complicated, time consuming task. Not just for researchers, but also for customs and producers in beneficiary countries, since they often lack the resources (e.g. a computer, internet access, etc.).

Box 4.3 How to find the applicable tariff? 


\section{LDC exports to the EU before Everything But Arms}

What value does the EU EBA initiative have for least developed countries? To get a complete answer to this question, one should compare production and trade patterns in LDCs before and after its implementation. This approach is followed in section 6 . This section compares tariff schemes before and after EBA implementation, to get a first indication of EBA's impact on trade potential.

\section{Preference margins before EBA}

This section draws on a study by Bora et al. (2002), from which table 5.1 was reproduced. It shows the 1998 level of EU trade protection by product category and country. Numbers in the table may be interpreted as effective tariff rates in percentage of the value of the imported product. Note that these are not true tariffs, as specific tariffs are excluded.

The table reports on LDCs Bangladesh, Malawi, Tanzania, Uganda, Zambia and a group of LDCs from Sub-Sahara Africa. Of these, only Bangladesh is not an ACP country. If two tariff schemes apply, which is the case for the African LDCs, then the lowest tariff is reported. In 1998, LDC preferences were generally deeper than ACP preferences. The specification of sectors is most detailed in those products relevant to LDCs, including food and fibres. Manufactures and services have been aggregated in one sector each. The interpretation of sectors is straightforward, except for 'other food products', which includes processed fish.

In 1998, LDCs were confronted with effective tariff barriers to EU markets for selected sectors only. Practically all non-agricultural products and services saw tariffs exempted. ${ }^{1}$ There were three categories of agricultural protection in 1998, each of which stands to benefit differently from EBA's immediate elimination of tariff barrier for all agricultural goods except rice, sugar and bananas. First, for oilseeds, forestry and fishing products, tariff barriers were nonexistent. EBA had no direct effect on market access, except that, possibly, several Asian and African LDCs benefit from easier rules for fishing products. Second, before EBA there were high tariffs of 20 to $100 \%$ of value for paddy and processed rice, cereals, sugar and dairy. Immediate tariff reduction under EBA was largest percentage-wise for cereals $(37 \%)$ and dairy $(51 \%)$. These sectors stand to gain from the arrangement, but typically requirements for export have to be met. Third, before implementation of EBA low tariffs of fewer than 5\% and substantial seasonal duties were levied on vegetables, fruit, nuts, livestock and animal products, other food products, beverages, tobacco, and vegetable oils and fat. Protection for meat and meat products varied.

\footnotetext{
${ }^{1}$ In fact, just $3 \%$ of LDC exports to the EU were charged a tariff, according to Bora et al. (2002, p.18). They weighed tariff lines by trade flow. Their analysis thus excludes the trade impact of prohibitive tariffs.
} 
The expected impact of EBA on LDC export performance differs by sector. Provided here are preliminary expectations of selected sectors based on LDC exports to EU in 2000. The analysis follows down the rows of table 5.1, and matches tariff data to trade data provided in Appendix 2. The case of sugar is discussed in box 6.1.

- $\quad$ Rice. All other things equal, the phaseout of tariffs on LDC rice between 2006 and 2009 will create preference margins of over $60 \%$ compared to all competitors. Asian LDC exporters such as Bangladesh will earn substantial terms of trade rents, while supply constraints prevent large increase of market share on the EU market. Increased trade volume will occur mainly at the expense of traditional Asian exporting developing countries (Vietnam, China, India) whose GSP preferences erode.

- Cereals. The direct gains to LDCs from cereal tariff reduction are minimal, as just half of one percent of cereal imports to the EU is of LDC origin. However, those African LDCs able to produce a grain surplus may well gain from well-priced outlet opportunities on the EU market.

- Vegetables, fruit and nuts. Over $40 \%$ of LDC exports to EU consist of these fresh products, so any tariff reduction should have significant impact. EBA eliminates average effective tariffs for LDC exports from $2.3 \%$ in 1998, plus substantial specific tariffs and seasonal duties. Remaining trade barriers are the entry prices for horticultural products (see box 4.1). After implementation of EBA, the preference margin to LDCs with the tariffs of competitors increases up to almost $15 \%$ ad valorem. As a result, export potential for already substantial vegetable exporters such as Senegal, Ethiopia, Madagascar and Uganda increases.

- $\quad$ Meat and meat products. Under EBA, the 14\% share of meat and meat products in LDC exports to EU may increase somewhat. Tariff cuts for LDCs between 10 and $20 \%$ are quite substantial, and may imply a threat to other developing country suppliers.

- Dairy. In 2000, LDC share in EU dairy imports was one hundredth of one percent. EBA eliminates a 51\% tariff on this trade. With specific tariffs added, their may have been a situation of a prohibitive tariff. Because of the geographical distance of LDCs to the EU, it is unlikely that dairy trade will pick up under a zero tariff.

- Beverages and tobacco. EBA reduces effective tariffs on major LDC export crops coffee, tea, tobacco and cocoa by $1.2 \%$. Over $10 \%$ of coffee and tea imports are from LDC origin, and nearly $8 \%$ of tobacco. Main current LDC exporters of coffee, tea and tobacco are Uganda, Ethiopia, Malawi and Tanzania. In Africa, these are likely to take over trade from regional competitors such as Ivory Coast and Ghana, both ACP countries.

The expected gains in export potential may or may not materialise. One necessary condition for increased exports from the LDCs is that products comply with increasingly stringent safety and quality requirements on high-income food markets. 
Table 5.1a EU: effective tariff rates in 1998, by sector and import country

\begin{tabular}{|c|c|c|c|c|c|c|c|c|c|}
\hline Sectors & $\begin{array}{l}\text { Austra- } \\
\text { lia } \\
\text { New } \\
\text { Zealand }\end{array}$ & China & $\begin{array}{l}\text { Other } \\
\text { deve- } \\
\text { loped }\end{array}$ & Japan & $\begin{array}{l}\text { Rest of } \\
\text { Asia }\end{array}$ & $\begin{array}{l}\text { Bang- } \\
\text { ladesh }\end{array}$ & Canada & $\begin{array}{l}\text { United } \\
\text { States }\end{array}$ & $\begin{array}{l}\text { Latin } \\
\text { America } \\
\text { \& Carrib- } \\
\text { bean }\end{array}$ \\
\hline Paddy rice & 65 & 65 & 65 & 65 & 65 & 62 & 65 & 65 & 65 \\
\hline Cereals & 60 & 45 & 49 & 45 & 49 & 37 & 59 & 46 & 46 \\
\hline Vegetable, fruits, nuts & 15 & 15 & 15 & 15 & 15 & 2 & 15 & 15 & 15 \\
\hline Oil seeds & 0 & 0 & 0 & 0 & 0 & 0 & 0 & 0 & 0 \\
\hline Sugar & 76 & 77 & 76 & 76 & 81 & 80 & 77 & 76 & 77 \\
\hline Plant-based fibers & 0 & 0 & 0 & 0 & 0 & 0 & 0 & 0 & 0 \\
\hline Other crops & 3 & 3 & 3 & 3 & 3 & 0 & 3 & 3 & 3 \\
\hline Livestock, animal products & 2 & 7 & 8 & 33 & 7 & 5 & 13 & 18 & 6 \\
\hline Forestry & 2 & 1 & 0 & 0 & 1 & 0 & 1 & 1 & 4 \\
\hline Fishing & 3 & 0 & 0 & 0 & 0 & 0 & 8 & 7 & 4 \\
\hline Coal, oil, gas and minerals & 0 & 0 & 0 & 0 & 0 & 0 & 0 & 0 & 0 \\
\hline Meat and meat products & 84 & 32 & 35 & 61 & 35 & 13 & 85 & 65 & 65 \\
\hline Vegetable oils and fats & 11 & 11 & 11 & 11 & 11 & 0 & 11 & 11 & 11 \\
\hline Dairy products & 88 & 88 & 88 & 88 & 88 & 51 & 88 & 88 & 88 \\
\hline Processed rice & 87 & 87 & 87 & 87 & 87 & 87 & 87 & 87 & 87 \\
\hline Other food products & 29 & 29 & 29 & 29 & 29 & 2 & 29 & 29 & 29 \\
\hline Beverages and tobacco & 8 & 8 & 8 & 8 & 8 & 1 & 8 & 8 & 8 \\
\hline Textiles & 1 & 10 & 4 & 9 & 8 & 0 & 9 & 9 & 6 \\
\hline Wearing apparel & 8 & 11 & 9 & 13 & 8 & 0 & 11 & 12 & 6 \\
\hline Leather products & 0 & 10 & 0 & 6 & 3 & 0 & 7 & 5 & 2 \\
\hline Manufactures & 2 & 5 & 0 & 5 & 2 & 0 & 2 & 3 & 1 \\
\hline Services & 0 & 0 & 0 & 0 & 0 & 0 & 0 & 0 & 0 \\
\hline
\end{tabular}

\section{The utilisation of preferences}

From the above, it follows that EBA in general brings modest tariff reductions only. This is understandable, given that LDCs had already been granted tariff and quota free access to the EU for many products. But exporters often fail to trade on the preference margin they are entitled to. Such a discrepancy between (potential) preference margins and the effect with which these are used is expressed by the so-called utilisation rate. Because of the costs of qualifying products for the preferential tariff, not all preferences are put to use. Utilisation is then normally below $100 \%$. Unfortunately, little has been published on utilisation rates outside the UN institute for trade and development, UNCTAD. Between 1998 and 2000, in many instances of LDC trade to Quad countries, less than 50\% of eligible preferences were utilised (UNCTAD, 2001a). The utilisation rate for exports from least developed countries (ACP and non-ACP) to the EU in 1999 was estimated at less than one 
third. ${ }^{1}$ For all developing country beneficiaries in the European Union market, UNCTAD estimates the utilisation rate at about $56 \%$ as against about $27 \%$ from the LDCs.

Table 5.1b EU: effective tariff rates in 1998, by sector and import country

\begin{tabular}{|c|c|c|c|c|c|c|c|c|c|}
\hline Sectors & $\begin{array}{l}\text { Eastern- } \\
\text { Europe } \\
\text { and FSU }\end{array}$ & $\begin{array}{l}\text { Middle } \\
\text { East }\end{array}$ & $\begin{array}{l}\text { North } \\
\text { Africa }\end{array}$ & Malawi & $\begin{array}{l}\text { Tanza- } \\
\text { nia }\end{array}$ & Zambia & $\begin{array}{l}\text { Ugan- } \\
\text { da }\end{array}$ & $\begin{array}{l}\text { Rest of } \\
\text { Sub- } \\
\text { Sahara } \\
\text { Africa }\end{array}$ & $\begin{array}{l}19 \\
\text { ROW }\end{array}$ \\
\hline Paddy rice & 65 & 65 & 65 & 62 & 62 & 62 & 62 & 62 & 65 \\
\hline Cereals & 47 & 51 & 51 & 37 & 37 & 37 & 37 & 37 & 47 \\
\hline Vegetable, fruits, nuts & 15 & 15 & 15 & 2 & 2 & 2 & 2 & 2 & 15 \\
\hline Oil seeds & 0 & 0 & 0 & 0 & 0 & 0 & 0 & 0 & 0 \\
\hline Sugar & 77 & 101 & 77 & 75 & 103 & 75 & 85 & 77 & 77 \\
\hline Plant-based fibers & 0 & 0 & 0 & 0 & 0 & 0 & 0 & 0 & 0 \\
\hline Other crops & 3 & 3 & 3 & 0 & 0 & 0 & 0 & 0 & 3 \\
\hline Livestock, animal products & 16 & 13 & 6 & 4 & 5 & 3 & 3 & 4 & 11 \\
\hline Forestry & 0 & 0 & 2 & 0 & 0 & 0 & 0 & 0 & 1 \\
\hline Fishing & 6 & 1 & 11 & 0 & 0 & 0 & 0 & 0 & 11 \\
\hline Coal, oil, gas and minerals & 0 & 0 & 0 & 0 & 0 & 0 & 0 & 0 & 0 \\
\hline Meat and meat products & 38 & 46 & 75 & 10 & 10 & 9 & 19 & 14 & 55 \\
\hline Vegetable oils and fats & 11 & 11 & 11 & 0 & 0 & 0 & 0 & 0 & 11 \\
\hline Dairy products & 88 & 88 & 88 & 51 & 51 & 51 & 51 & 51 & 88 \\
\hline Processed rice & 87 & 87 & 87 & 87 & 87 & 87 & 87 & 87 & 87 \\
\hline Other food products & 29 & 29 & 29 & 3 & 2 & 2 & 2 & 2 & 29 \\
\hline Beverages and tobacco & 8 & 8 & 8 & 1 & 1 & 1 & 1 & 1 & 8 \\
\hline Textiles & 6 & 2 & 6 & 0 & 0 & 0 & 0 & 0 & 10 \\
\hline Wearing apparel & 7 & 1 & 10 & 0 & 0 & 0 & 0 & 0 & 12 \\
\hline Leather products & 5 & 2 & 2 & 0 & 0 & 0 & 0 & 0 & 7 \\
\hline Manufactures & 2 & 1 & 2 & 0 & 0 & 0 & 0 & 0 & 3 \\
\hline Services & 0 & 0 & 0 & 0 & 0 & 0 & 0 & 0 & 0 \\
\hline
\end{tabular}

Source: reproduced from Bora et al. (2002), table IV.A.4, rounded. Based on calculations of 1998 data on ad-valorem tariffs and calculated tariff equivalents of agricultural quotas only; specific tariffs are excluded.

Export products for which utilised preferences were low included textiles and clothing, fish and preparations of fruit and other plant material. Low utilisation rates should be attributed to the fact that procedures to receive the duty free access are too complicated. Many of these procedures are related to the difficulties of complying with rules of origin. The Bangladesh garment industry serves to illustrate the point. Between 1995 and 2000, rules of origin for garment imports under the EU GSP scheme were changed often, and resulted in volatile utilisation rates for Bangladesh garment exporters (UNCTAD, 2001b).

\footnotetext{
${ }^{1}$ Utilisation of preferences was higher for exports to other Quad countries, but in the late 1990s the preference schemes of Canada, United States and, to a lesser extent, Japan also, covered far fewer products than the EU scheme.
} 
By and large, these rules remain unchanged under the EBA-amendment. Thus, LDC exporters, despite being eligible to improved preferential market access, frequently pay MFN tariffs to enter Quad markets.

Before EBA, tariff preferences granted by the EU covered $99 \%$ of all LDC trade, but the utilisation rate was below 50\%. Hence, any initiative to increase EU market access for LDCs should addressed the practical constraints to market access. EBA is disappointing from that perspective (UNCTAD, 2001a). 


\section{Estimated effects of preferences in agricultural trade}

Developing countries that currently have preferential access to high-income markets may wish to defend their preferences in the upcoming Doha Round of negotiations under the WTO. However, one could also argue that these countries are better off with a multilateral reduction in MFN tariffs, even though their preferences would erode in the process of liberalisation. The position that such countries take in the negotiations will naturally depend on their specific situation, but also on their interest: positions will differ whether interest is purely in trade, or in a broader concept of economic development.

For exporting countries, trade interests are driven by the maximisation of export sales revenues through the terms of trade. Economic development interests follow from overriding objectives such as long-term export growth and sustainable use of the natural resource base. Such development analyses therefore delve into relative prices, sectoral allocation and exchange rate changes (Bora et al., 2002:48), rather than direct trade benefits.

Also on the side of the country granting the preference there is a useful distinction to be made between a narrow and a broader perspective. In narrow terms, donor countries may evaluate the costs of a scheme by the tariff revenue foregone and the extent to which domestic products are replaced by imports. Taking the broader view, these elements are but part of the bigger picture, which the question arises whether the preference schemes contribute to the desired structure of the economy, or work against it.

\subsection{Trade perspective on preferential access to protected markets}

When a country is given the opportunity to export some of its products on a preferential tariff to a protected market, the following trade effects may occur:

- $\quad$ increased volume of export to the protected market. Country groups achieving 10 percent export growth from trade preferences appear to be major gainers; most individual countries gain much less. Historical evidence about the trade impact of the preferential tariff schemes is not abundant. According to Pomfret (1997), there is conclusive evidence that GSP schemes up to the mid-1980s generated export growth in beneficiary countries. Gains were distributed unequally; most accrued to a select group of countries where domestic conditions were favourable to economic development, such as South Korea and Taiwan. This pattern of distribution also shows in the current EBA-studies;

- $\quad$ increased rents to exporters associated with a terms of trade advantage. Export revenue gains are likely to increase with the strength of the improvement in the terms of trade with the importing country, but these may be concentrated in a small selection of products. These terms of trade advantages can be substantial in protected markets. See table 6.1 on the divergence of world prices and EU intervention prices. It reports, for a selection of agricultural goods important to low-income countries, the price 
premium an exporter receives when he sells products at EU intervention prices instead of world market prices. Note that the premium for rice, sugar and bananas - three products for which liberalisation under EBA is delayed - is among the largest; reduced tariff revenue in the donor countries. When products from beneficiary countries replace other countries' exports on the donor market, there is an immediate loss to the donor of tariff revenues foregone. In the case of EBA-like access granted to LDCs, this has minor impact on EU welfare due to the small market share of LDC products. See Appendix 2 for detail on market shares.

Table 6.1 EU price premium, 1999-2000

\begin{tabular}{|c|c|c|c|}
\hline \multirow[t]{2}{*}{ Product } & \multicolumn{2}{|c|}{ Price $(€ /$ ton $)$} & \multirow{2}{*}{$\begin{array}{l}\text { Price } \\
\text { premium } \\
(\%)\end{array}$} \\
\hline & EU & World & \\
\hline Wheat & 133 & 118 & 13 \\
\hline Maize & 140 & 92 & 52 \\
\hline Pig meat & 1,120 & 1,113 & 1 \\
\hline Sheep Meat & 3,333 & 1,476 & 126 \\
\hline Whole Milk Powder & 2,605 & 1,384 & 88 \\
\hline Skimmed Milk Powder & 2,055 & 1,419 & 45 \\
\hline Butter & 2,954 & 1,307 & 126 \\
\hline Cheese & 3,500 & 2,154 & 62 \\
\hline
\end{tabular}

Source: European Commission (2001c).

\subsection{Expected trade effects of EBA-like initiatives}

Recent ex-ante studies estimate export growth from EBA-like access to all Quad markets for all beneficiary countries in the range of 3 to $14 \%$ (see table 5.1 ). ${ }^{1}$ The results in table 6.2 should, however, receive cautious interpretation. Each of the studies reports trade changes for a specific category of exports: Ianchovichina et al. (2000) report on non-oil exports of 37 least developed or highly indebted poor countries in Sub-Sahara Africa; Bora et al. (2002) report on worldwide LDC exports; Hoekman et al. (2001) report on LDC exports subject to peak tariffs at EU, US, Japan and Canada, the Quad markets. See also box 4.2 .

Each of the three studies estimates the impact of two trade preference schemes to LDCs: EBA-like access to the EU and similar unrestricted access to all Quad markets. There is consensus that the latter generates substantially stronger export increases than

\footnotetext{
${ }^{1}$ Not reported here are results by Kerkelä et al. (2000), which compares trade and welfare of the African ACP countries under simulated zero-duty or GSP conditions. Under both scenarios their results do not compare easily to those in table 5.1, either because the zero-duty tariff is reciprocal (i.e. tariff and non-tariff barriers on imports from EU to these countries are also removed) or because under GSP the remaining tariff barriers for agricultural goods are substantial.
} 
EU's EBA only. The lion's share of this gain comes at the cost of other low-income exporters. On EU markets, African LDCs and African non-LDC developing countries show quite similar trade patterns - a finding that may be attributed to the Lomé/Cotonou arrangements for ACP countries - implying that diversion effects of European EBA will mainly draw trade away from African developing countries towards the African LDCs.

However, LDC's weight is too small for a substantial impact (Bora et al.; Ianchovichina et al.). Hoekman et al. (2001) also find substantial diversion of agricultural trade under the EBA access rules, from developing countries to LDCs in general. Regarding segments protected with peak tariffs specifically, a match to current LDC exports reveals that the fruit \& vegetable sector in LDCs takes over trade from competitor developing countries.

Trade creation effects are small (especially in relative terms) with one exception; in the sugar market domestic products are prone to being crowded out by LDC or developing country products. More trade creation occurs when the other Quad countries follow the EU initiative for duty-free and quota-free access to LDC products. According to Hoekman et al. the countries that stand to gain most from unrestrained access are those where excess supply exists in products that were kept out of Quad markets by prohibitive tariffs or small TRQs. From that perspective relevant markets for LDCs are apparel and crops such as rice and groundnuts. Apparel products are levied a 15 to $20 \%$ tariff in Canada and the United States, and preferences margins for LDCs are minimal. Japan protects its rice market with peak tariffs of over $60 \%$ and small TRQs. For Bangladesh and other small textiles and clothing suppliers in Asia, export potential will likely increase. Likewise, several SubSaharan countries may benefit from the opening in the Japanese tariff wall. However, the required export supply is currently to small for major welfare gains and enhancing capacity will draw resources away from industrial activity. In sum, removal, on preferential terms, of prohibitive tariff and non-tariff barriers on the grains market in Japan and the textiles and clothing market in Canada and the United States, may induce substantial trade creation from LDCs.

\subsection{Trade effects of preference erosion}

LDC trade preferences may lose part of their 'exclusiveness' in two ways. First, as a result of extending a preference scheme to more countries that produce similar goods. Hoekman et al., by proxy, apply unrestricted access to all countries in the GSP scheme. In such an experiment, any LDCs that are not least-cost supplier, loses market share to a more efficient developing country. Fish and sugar are products for which trade shifts. Second, LDCs are also affected when MFN tariffs decrease. When the tariffs applicable to non-LDCs decrease, this causes the preferences of LDCs to erode. Both Ianchovichina et al. and Hoekman et al. (2001) estimate the trade effects of a decrease in MFN rates, by 25 and 5\%, respectively. In all cases, starting point is EBA-like access to all Quad markets. The studies indicate that LDC exporters might lose trade to other low-income exporters due to preference erosion, but the loss is not likely to be severe. It might cause redirection of substantial trade flows from one trade partner to the other. One would expect some welfare losses to 
Table 6.2 LDC exports under preferential market access (change from base case) a)

\begin{tabular}{|c|c|c|c|c|}
\hline \multirow[t]{2}{*}{ Scenario } & \multirow[t]{2}{*}{ Data } & \multicolumn{2}{|l|}{$\begin{array}{l}\text { Change to } \\
\text { base case }\end{array}$} & \multirow[t]{2}{*}{ Impact relative to base case } \\
\hline & & USD mln & $\%$ & \\
\hline \multicolumn{5}{|l|}{ Ianchovichina et al., 2000} \\
\hline EU_EBA & SSA37 world exports & 513 & 3 & $\begin{array}{l}\text { Increase: plant fibre exports (23); no other } \\
\text { Effects }\end{array}$ \\
\hline Quad_EBA & SSA37 world exports & 2,543 & 14 & $\begin{array}{l}\text { Increased exports to Japan by } 400 \% \text { (mostly } \\
\text { cereals) at cost of EU exports; decreased: } \\
\text { crops }(-12) \text {, leather, minerals }\end{array}$ \\
\hline Quad_EBA_MFN $=75 \%$ & SSA37 world exports & 2,467 & 14 & $\begin{array}{l}\text { Increased exports to Japan by } 280 \% \text {, to EU } \\
\text { and to developing countries (cereals and } \\
\text { livestock mostly) }\end{array}$ \\
\hline Quad_EBA_CAP $=\mathrm{Jap}=0$ & SSA37 world exports & 2,954 & 16 & $\begin{array}{l}\text { As Quad_EBA plus increased value of } \\
\text { cereal and meat exports }\end{array}$ \\
\hline \multicolumn{5}{|l|}{ Bora et al., 2002} \\
\hline EU_EBA & LDC world exports & 386 & 1 & $\begin{array}{l}\text { Increased exports rice (paddy and proc- } \\
\text { essed), cereals and sugar to EU }\end{array}$ \\
\hline Quad_EBA & LDC world exports & 1,582 & 3 & $\begin{array}{l}\text { Increased SS-Africa grain exports to Japan } \\
\text { and apparel exports South Asia to USA; all } \\
\text { rice producers increase export to Japan }\end{array}$ \\
\hline \multicolumn{5}{|l|}{ Hoekman et al., 2001} \\
\hline EU_EBA & $\begin{array}{l}\text { LDC world exports peak } \\
\text { products }\end{array}$ & 185 & 1 & $\begin{array}{l}\text { Increased peak exports to EU by } 37.5 \% \text {, } \\
\text { mostly sugar products }\end{array}$ \\
\hline Quad_EBA & $\begin{array}{l}\text { LDC world exports peak } \\
\text { products }\end{array}$ & 2,500 & 11 & $\begin{array}{l}\text { Potential export surge (in order of value) } \\
\text { clothing to Canada; clothing to US; sugar to } \\
\text { Japan; tobacco to US; sugar to EU. Trade } \\
\text { creation into Quad USD } 132 \text { million }\end{array}$ \\
\hline EU_GSP=EBA & $\begin{array}{l}\text { LDC world exports peak } \\
\text { products }\end{array}$ & 5 & 1 & $\begin{array}{l}\text { LDC fish exports decrease; GSP peak } \\
\text { Exports to world increase by USD } 18 \\
\text { billion, mostly sugar }\end{array}$ \\
\hline Quad_GSP=EBA & $\begin{array}{l}\text { LDC world exports peak } \\
\text { products }\end{array}$ & 1,366 & 6 & \\
\hline EU_MFN=95\% & $\begin{array}{l}\text { LDC world exports peak } \\
\text { products }\end{array}$ & -47 & -10 & $\begin{array}{l}\text { Most LDC peak exports to world (fish, } \\
\text { cereals) decrease to benefit of other } \\
\text { developing countries; LDC sugar exports } \\
\text { slightly up }\end{array}$ \\
\hline
\end{tabular}

Under EU_EBA, all products of LDCs are granted duty-free and unlimited access to the EU market; under Quad_EBĀ these conditions apply to all Quad countries: US, EU, Canada and Japan; under EU_GSP=EBA, these conditions apply not only to LDCs, but all countries in the GSP scheme of the EU; likewise under Quad_GSP=EBA, but for all GSP countries in all Quad GSP schemes. Under Quad_EBA_MFN=x\%, MFN tariffs are reduced to $\mathrm{x}$ percent of previous levels.

a) Results from Hoekman et al. (2001) apply only to tariff peak products and indicate the change of exports under tariff lines that were over $15 \%$ before; simulations ignore existing quotas. Ianchovichina et al. (2000) results apply only to a sub-set of 37 Sub-Saharan LDCs.

go along with such trade diversion, as LDC exporters are first replaced in the high-value markets. Below follows a discussion of welfare effects. 


\subsection{Economic development view on preferential access}

When assessing the value of trade preferences to the economic development of beneficiary countries, one should take more effects into account than the trade impact only. An analysis of welfare effects may include the trade-distorting impact of preferential access on resource allocation and factor costs in the long run. Policies that deal with rents from prolonged access to producer rents in protective markets are crucial. Also, the consequences of various policy assumptions should be taken into account.

The section continues with a summary of three studies on welfare impact of preferential trade that make use of a computable economic model. These distinguish between terms-of-trade and allocation effects. The summary here follows three potential policies that may become relevant in the near future. One follows protectionist tendencies in agricultural policy and a continuation of status quo with deep preferences to low-income countries. Two options go ahead of liberalised agricultural policies, one with focus on decreased subsidies and price intervention, and another with a focus on reduction of MFN tariffs.

\section{Option 1: Deep preferences under continued domestic agricultural policies}

See EU-EBA and Quad-EBA in table 5.1. Under EBA-like access to Quad markets, exporters in beneficiary countries benefit mostly from openings in the Japanese agricultural markets and the apparel marketing Canada and US. The potential of earning terms of trade gains due to price premiums are substantial, especially in Japan. According to Bora et al. (2002), however, welfare gains follow mainly from improved allocation efficiency. This refers to the match between comparative advantages and factor use over sectors. When all Quad markets are opened up, there is more option for reallocation. Consequently, gains are bigger than under the EU EBA initiative only.

Both Ianchovichina et al. (pp. 17-18) and Bora et al. (p. 58) report that preferential access to EU and Japan agricultural markets draws resources in beneficiary countries away from non-tradable and manufacturing sectors towards the agricultural sector. Most relevant is whether the resources are used to build a viable agricultural processing sector, or purely used to facilitate exploitation of the natural resource stock.

\section{Option 2: Deep preferences under reduced domestic agricultural policies}

See Quad_EBA_CAP $=\mathrm{Jap}=0$ in table 5.1. Under this scenario, the price premium for foreign producers drops dramatically, as will happen when EU common agricultural policy is reformed with a shift from intervention prices to farmer income support. This will reduce the opportunity to accumulate rents and invest in economic development. The case is also relevant for sugar trade, as is clear from box 6.1. When sugar trade with LDCs is liberalised under EBA in 2009, EU prices are expected to be more in line with world prices.

In a footnote to their results, Ianchovichina et al. (2000) provide estimated trade benefits for beneficiary countries under completely eliminated subsidies on Japanese and EU agricultural production. The estimated gains, with EBA-like access to all Quad markets 
as a base case, amount to a further USD 412 million. They report no evidence on welfare effects for LDCs, but these should be positive.

\section{Option 3: Multilateral tariff reduction}

In table 5.1, see Quad_EBA_MFN=x\%. Hoekman et al. find that options that extend zeroduty access to all developing countries or decrease MFN-tariff will by $5 \%$ entail much more cost to the donor countries. Ianchovichina et al. find that due to trade diversion half of the welfare gains for African countries under the cooperative Quad initiative would flow to other low-income countries, if these preferences were to erode due to a $25 \%$ cut in MFN tariffs.

Welfare impact in importing countries is composed of tariff revenue loss due to trade diversion and consumer surplus gain due to trade creation. Strength of the latter depends upon the notion whether the favourable country is the least-cost source for a particular product; if it is not, preferential trade will necessarily lead to lower welfare in the importing country than under free trade (Ianchovichina et al., 2000:8). However, by the very small weight of LDCs in world trade, the initiatives results in little displacement of domestic products by imports and in minor tariff revenue losses. Therefore, various reports agree with Hoekman et al. (2001, p. 727) that 'an immediate offer of duty free access (for LDC exports) is a low cost option for the Quad to offer' - costs in terms of rising Quad import coefficient. Table 6.3 provides a summary of all welfare and trade effects of a concerted to provide unrestricted access of LDC products to the markets of the Quad.

\begin{tabular}{|c|c|c|}
\hline & LDCs & Quad \\
\hline $\begin{array}{l}\text { Trade } \\
\text { impact }\end{array}$ & $\begin{array}{l}\text { Export potential may grow by } 3-13 \% \text {, } \\
\text { mostly due to broader range of products } \\
\text { covered by preference of US and Canada } \\
\text { (textiles and clothing) and Japan (rice and } \\
\text { nuts) } \\
\text { Individual countries affected by prohibitive } \\
\text { tariffs may gain more if supply can expand } \\
\text { Preference utilisation rate is unlikely to rise } \\
\text { due to rules of origin and cumulating value- } \\
\text { added; thus limited rise of export to EU }\end{array}$ & $\begin{array}{l}\text { Minor tariff revenue losses and limited } \\
\text { trade creation; except in Japan due to food } \\
\text { imports } \\
\text { EU (and ACP) sugar farmers and processors } \\
\text { loose stake to LDC producers } \\
\text { Trade versus aid argument for granting } \\
\text { preferences }\end{array}$ \\
\hline $\begin{array}{l}\text { Economic } \\
\text { development }\end{array}$ & $\begin{array}{l}1 \text { or } 2 \% \text { welfare increase if export potential } \\
\text { can be exploited } \\
\text { Resources move into the agricultural sector, } \\
\text { away from light manufactures. Short term } \\
\text { gains, but when trade preferences erode } \\
\text { transformation is more difficult. } \\
\text { Impact of preference erosion is limited } \\
\text { Positive effects on long term depend on al- } \\
\text { location of short term price rents and other } \\
\text { temporary windfalls } \\
\text { Possible depletion of natural resource stock } \\
\text { with reallocation towards agricultural sector }\end{array}$ & $\begin{array}{l}\text { Low welfare cost, as a result of limited } \\
\text { trade creation and efficiency loss } \\
\text { Preferences on agricultural goods are linked } \\
\text { with reform of agricultural policies, e.g. EU } \\
\text { sugar and Japan rice } \\
\text { Are preferences of use as a tool to influence } \\
\text { supply side in developing countries to the } \\
\text { benefit of donor country consumers? }\end{array}$ \\
\hline
\end{tabular}


Sugar is one of EU's most heavily protected agricultural products, with ad valorem tariffs of 75 to $103 \%$ for several LDCs (table 5.1). These high tariffs have to bridge the gap between the low-cost producing countries and the costs EU producers have to make to produce sugar, which can be over two or three times higher. High tariffs like these, hamper exports from low-cost producing countries like Mozambique and Brazil.

However, all preferential schemes of the EU (GSP, Cotonou and EBA) grant tariff preferences and/or tariff quota to their beneficiaries. Next to these schemes several bilateral arrangements and the Sugar Protocol, which consists of 17 countries, including 4 LDCs, regulate preferences for sugar products. The height of the preferences and the product coverage of all these schemes, arrangements and initiatives differ considerably. The GSP scheme, for instance, grants much lower preferences and covers a smaller product range than the Cotonou Agreement. Everything But Arms initiative should give duty free access to all LDC exports, but sugar is excluded from liberalisation until 2006, after which tariffs will gradually be reduced and completely abolished by 2009. In the meantime a new quota for raw sugar will be established and expanded by $15 \%$ annually, making it possible for LDCs to expand their exports under the preference-giving scheme. As can be seen, it is vital for an exporter or producer to know to which scheme he can apply, however difficult it might be to determine the tariff scheme, tariffs, preferences and requirements for products.

This jumble of tariffs and preferences is certainly not the only problem (developing) countries face, when exporting sugar products. The EU sugar policy hampers them as well. This policy, which was established in 1967, is based on the principle of a fair income for producers and processors of raw sugar. This was done by the introduction of guaranteed prices, resulting in an incentive to produce more than necessary to meet internal demand. In order to stop the overproduction, the EU assigned production quota to each member state. However, the objected result was never met, with overproduction mounting to 7 million tonnes on a total production of 17 million in the year 2000. The biggest part of this overproduction is exported with export subsidies, in order to be able to guarantee a fair income for the producers. These subsidised exports are extremely competitive (cheap), which results in a white sugar market share of $40 \%$, making the EU the biggest exporter in the world. Naturally, these distortions, mainly caused by the EU, have a negative effect on the exports of countries with a comparative advantage in sugar.

Another consequence of the sugar policy is that, despite its own overproduction, the EU imports sugar from developing countries (approximately 1.5 million tonnes in 2000). Since the EU already has an excess amount of sugar, it can be said that the imported sugar is directly exported (with subsidy) to the world, where it competes with sugar from the aforementioned developing countries.

In short, due to the complicated structure of the tariff schemes, the large amounts of subsidised exports from the EU and the re-export of sugar from developing countries, these countries are severely limited in their possibilities to boost their export and development. With the coming of the EBA initiative and the ongoing liberalisation of world trade, however, the EU and also the US have to review and adapt their sugar policies. This might give some possibilities for low-cost producing countries.

Box $6.1 \quad$ EU sugar trade policy 


\section{Conclusions}

The Everything But Arms (EBA) amendment to the preference scheme of the European Union (EU) will have limited effect on export potential and welfare in the least developed countries (LDCs). Before EBA, almost 100 percent of LDC products were covered under alternative preference schemes, but utilisation rates were quite low. As the amendment does little to simplify rules of origin and cumulation of value added, utilisation rates are not likely to rise. However, both the sugar sector and the fruit \& vegetable sector in LDCs could benefit from the competitive edge that puts LDCs in a favourable trade position. Under EBA, the preference margin of LDCs fruit and vegetable to other developing countries under the GSP scheme is over $10 \%$; the preference over ACP countries is just $2 \%$. If all countries in the Quad (EU, US, Canada and Japan) remove tariff and non-tariff barriers to LDCs, these countries gain access to market segments in Quad that were effectively barred before. This will result in trade creation and trade diversion with potential negative effects on producers in the Quad and other developing countries. The weight of LDCs in global trade, is however too small for substantial losses.

The current issue is whether there is a future to trade preferences for products from the South. It should be clear from the above that exports from the least developed countries to the Quad are sensitive to the trade preferences granted. Japan, Canada and the US could very well extend preferences at a small cost to domestic producers. While the utilisation rate of EU preferences should increase, the obligation for change lies with EU and LDCs alike. The EU would do well to simplify compliance with their rules of origin. From the side of LDCs, there is an obligation to improve on administrative practices, which sometimes induce trade at MFN tariffs where products are eligible to preferential rates.

When LDCs are granted deep preferences under continued domestic agricultural policies in the Quad, resources in LDCs will move towards the agricultural sector. Welfare in LDCs improves as exporters earn large price premiums. The return to these short-term rents depends heavily on the investment spending of these rents. That, at least, is the argument of Deaton (1999) for a case of temporarily booming commodity prices that has similar implications. On the long run, the rents will decrease as domestic agricultural policies in the Quad are cut back, as MFN tariffs decrease under further trade liberalisation, and as zero-tariff preferences are extended to peer developing countries. The studies reviewed in this report agree that, for LDCs, the trade diverting impact of extending preferences to non-LDCs is quite small. The negative effect of MFN tariff reductions is stronger, as a result of competition with lower-cost suppliers in non-LDC developing countries. Moreover, as Kerkelä et al. (2000) show, governments in several African countries would loose an important source of revenues under reciprocal liberalisation. If MFN tariffs and agricultural support in the Quad are reduced, it is necessary for LDCs that peer developing countries reduce tariff barriers too. As, among others, Van Meijl and Van Tongeren (2001) show, there are large potential gains to be expected for LDCs from liberalised South-South trade. 


\section{References}

AMAD database, the Agricultural Market Access Database, available at http://www.amad.org

Berkum, S. van, A.D. Westerman and C.J.W. Wolswinkel, De internationale locatie van de tuinbouw bij handelsliberalisatie. Report no. 6.02.11, LEI, The Hague, 2002.

Bora, Bijit, Lucian Cernat and Alessandro Turrini, Duty and quota-free access for LDCs: further evidence from CGE modelling, UNCTAD, New York, 2002.

CIA, World Factbook. On Indonesia: www.cia.gov/cia/publications/factbook/geos/iv.html

Court of Auditors, 2001, Special report No. 20/2000,

http://europa.eu.int/eur-lex/pri/en/oj/dat/2001/c_050/c_05020010215en00010030.pdf

Deaton, A., Commodity prices and growth in Africa. Journal of Economic Perspectives Vol 13, no. 3, 1999, pp. 23-40.

European Commission, EU council regulation No. 416/2001 amending the GSP scheme so as to extend duty-free access without any quantitative restrictions to products originating in the least developed countries, 28 February 2001, http://europa.eu.int/eurlex/pri/en/oj/dat/2001/1_060/1_06020010301en00430050.pdf (Everything But Arms), 2001a.

European Commission, EU council regulation no. 2501/2001, 10 december 2001, http://europa.eu.int/smartapi/cgi/sga_doc?smartapi!celexapi!prod!CELEXnumdoc\&lg=NL \&numdoc=32001R2501\&model=guichett, $2001 \mathrm{~b}$.

European Commission, Everything But Arms Proposal: Possible Impacts on the Agricultural Sector. Brussels, 2001c.

European Commission, EU council regulation No. 1602/2000 amending Regulation (EEC) No 2454/93 laying down provisions for the implementation of Council Regulation (EEC) No 2913/92 establishing the Community Customs Code, 24 July 2000, http://europa.eu.int/eur-lex/pri/en/oj/dat/2000/1_188/1_18820000726en00010132.pdf, 2000a.

European Commission, 2000b, Cotonou Agreement, http://europa.eu.int/scadplus/printversion/en/lvb/r12101.htm 
European Commission, EU council regulation No. 2820/98 applying a multiannual scheme of generalised tariff preferences for the period 1 July 1999 to 31 December 2001, 21 December 1998

Frandsen, S.E. (et al.), Modelling the EU sugar Policy: A study of policy reform scenarios, SJFI-working paper no. 13/2001, 2001.

Hoekman, Bernard, Francis Ng and Marcelo Olarreaga, Eliminating excessive tariffs on exports of least developed countries, Working Paper no. 2604, Washington DC: World Bank, 2001.

Hoekman, B., A. Mattoo and P. English (eds), Development, Trade and the WTO: A handbook. Washington DC: World Bank, 2002.

Ianchovichina, Elena, Aaditya Mattoo and Marcelo Olarreaga, Unrestricted market access for Sub-Sahara Africa: How much is it worth and who pays? Working Paper no. 2595, Washington DC: World Bank, 2000.

Kerkelä, L., J. Niemi, R. Vaittinen, Renegotiating the Lomé Convention: trade policy schemes and their effects for African regions. Working paper no. W-261. Helsinki: Helsinki School of Economics and Business Administration, 2000.

McCulloch, N., L.A. Winters and X. Cirera, Trade liberalization and poverty: a handbook. CEPR, London, 2001.

Meijl, H. van and F. van Tongeren, Multilateral trade liberalisation and developing countries: A North-South perspective on agriculture and processing sectors. Report no. 6.01.07, LEI, The Hague, 2001.

MinBuZa (Directie Duurzame Economische Ontwikkeling van het Ministerie van Buitenlandse Zaken), Beantwoording Motie Van Middelkoop en Dijksma (in Dutch). Ministry of Foreign Affairs, The Hague, 2002.

Oxfam, 2002, The Great Eu Sugar Scam: how Europe's sugar regime is devastating livelihoods in the developing world, Oxfam Briefing Paper no. 27, www.oxfam.org.uk/policy/papers/27sugar/27sugar.pdf

Pomfret, Richard, Regional Trade Agreements. Oxford University Press, 1997.

Resal Coordination, The 'Everything But Arms' initiative - What are its consequences for Resal countries, Technical note, SOLAGRAL, 1999. 
Tangermann, Stefan, The future of preferential trade arrangements for developing countries and the current round of WTO negotiations on agriculture. FAO Geneva Round Table on selected agricultural trade policy issues, 21 March 2001, discussion paper no. 3, FAO, Rome, 2001.

Topp, Vernon, Trade Preferences. ABARE, Canberra, 2001.

Trade and Environment database, American University. On EU's chocolate dispute: http://www.american.edu/projects/mandala/TED/chocolat.htm

UNCTAD, 2001a, Improving Market Access for Least Developed Countries. Report UNCTAD/DITC/TNCD/4

http://www.unctad.org/en/docs//poditctncd4.en.pdf

UNCTAD, 2001b, Duty and Quota Free Market Access for LDCs: An Analysis of Quad Initiatives. Report UNCTAD/DITC/TAB/Misc.7, in cooperation with the Commonwealth Secretariat 


\section{Appendix 1 Country list by tariff scheme}

\begin{tabular}{|c|c|c|}
\hline GSP (179 landen) & ACP (77 landen) & LDC $=$ EBA (49 landen) \\
\hline Afghanistan & & Afghanistan \\
\hline \multicolumn{3}{|l|}{ Algeria } \\
\hline \multicolumn{3}{|l|}{ American Samoa } \\
\hline Angola & Angola & Angola \\
\hline \multicolumn{3}{|l|}{ Anguilla } \\
\hline \multicolumn{3}{|l|}{ Antarctica } \\
\hline Antigua and Barbuda & Antigua and Barbuda & \\
\hline \multicolumn{3}{|l|}{ Argentina } \\
\hline \multicolumn{3}{|l|}{ Armenia } \\
\hline Aruba & & \\
\hline Azerbaijan & & \\
\hline Bahamas & Bahamas & \\
\hline Bahrain & & \\
\hline Bangladesh & & Bangladesh \\
\hline Barbados & Barbados & \\
\hline Belarus & & \\
\hline Belize & Belize & \\
\hline Benin & Benin & Benin \\
\hline Bermuda & & \\
\hline Bhutan & & Bhutan \\
\hline Bolivia & & \\
\hline Botswana & Botswana & \\
\hline Bouvet Island & & \\
\hline Brazil & & \\
\hline British Indian Ocean Territory & & \\
\hline Brunei Darussalam & & \\
\hline Burkina Faso & Burkina Faso & Burkina Faso \\
\hline Burundi & Burundi & Burundi \\
\hline Cambodia & & \begin{tabular}{|l} 
Cambodia \\
\end{tabular} \\
\hline Cameroon & Cameroon & \\
\hline Cape Verde & Cape Verde & Cape Verde \\
\hline Cayman Islands & & \\
\hline Central African Republic & Central African Republic & Central African Republic \\
\hline Chad & Chad & Chad \\
\hline Chile & & \\
\hline Christmas Islands & & \\
\hline Cocos Islands & & \\
\hline Colombia & & \\
\hline Comoros & Comoros & Comoros \\
\hline Congo & Congo & \\
\hline Cook Islands & Cook Islands & \\
\hline Costa Rica & & \\
\hline Côte d'Ilvoire & Cote d'Ivoire & \\
\hline Cuba & Cuba (niet ondertekend) & \\
\hline Cyprus & & \\
\hline Democratic Republic of Congo & Democratic Republic of Congo & Democratic Republic of Congo \\
\hline Djibouti & Djibouti & Djibouti \\
\hline Dominica & Dominica & \\
\hline Dominican Republic & Dominican Republic & \\
\hline East Timor & & \\
\hline Ecuador & & \\
\hline Egypt & & \\
\hline El Salvador & & \\
\hline Equatorial Guinea & Equitorial Guinea & \begin{tabular}{|l|} 
Equitorial Guinea \\
\end{tabular} \\
\hline Eritrea & Eritrea & Eritrea \\
\hline Ethiopia & Ethiopia & Ethiopia \\
\hline Falklands Islands & & \\
\hline Federated States of Micronesia & Federated States of Micronesia & \\
\hline Fiji & Fiji & \\
\hline French Polynesia & & \\
\hline French Southern territories & & \\
\hline Gabon & Gabon & \\
\hline Gambia & Gambia & Gambia \\
\hline Georgia & & \\
\hline Ghana & Ghana & \\
\hline Gibraltar & & \\
\hline Greenland & & \\
\hline Grenada & Grenada & \\
\hline Guam & & \\
\hline Guatemala & & \\
\hline Guinea & Guinea & Guinea \\
\hline Guinea-Bissau & Guinea-Bissau & Guinea-Bissau \\
\hline Guyana & Guyana & \\
\hline Haiti & Haiti & Haiti \\
\hline Heard Island and McDonald Islan & & \\
\hline Honduras & & \\
\hline India & & \\
\hline Indonesia & & \\
\hline Iran (Islamic Republic of) & & \\
\hline Iraq & & \\
\hline Jamaica & Jamaica & \\
\hline Jordan & & \\
\hline Kazakhstan & & \\
\hline
\end{tabular}




\begin{tabular}{|c|c|c|}
\hline Lesotho & Lesotho & Lesotho \\
\hline Liberia & Liberia & Liberia \\
\hline \multicolumn{3}{|l|}{ Libyan Arab Jamahiriya } \\
\hline \multicolumn{3}{|l|}{ Macao } \\
\hline Madagascar & Madagascar & Madagascar \\
\hline Malawi & Malawi & Malawi \\
\hline \multicolumn{3}{|l|}{ Malaysia } \\
\hline Maldives & & Maldives \\
\hline Mali & Mali & Mali \\
\hline Marshall Islands & Marshall Islands & \\
\hline Mauritania & Mauritania & Mauritania \\
\hline Mauritius & Mauritius & \\
\hline \multicolumn{3}{|l|}{ Mayotte } \\
\hline \multicolumn{3}{|l|}{ Mexico } \\
\hline \multicolumn{3}{|l|}{ Moldova } \\
\hline \multicolumn{3}{|l|}{ Mongolia } \\
\hline \multicolumn{3}{|l|}{ Montserrat } \\
\hline Morocco & & \\
\hline Mozambique & Mozambique & Mozambique \\
\hline Myanmar (ontvangt geen hulp) & & Myanmar (ontvangt geen hulp) \\
\hline Namibia & Namibia & \\
\hline Nauru & Nauru & \\
\hline Nepal & & Nepal \\
\hline Netherlands Antilles & & \\
\hline New Caledonia & & \\
\hline Nicaragua & & \\
\hline Niger & Niger & Niger \\
\hline Nigeria & Nigeria & \\
\hline Niue Island & Niue Island & \\
\hline Norfolk Island & & \\
\hline Northern Mariana Islands & & \\
\hline Oman & & \\
\hline Pakistan & & \\
\hline Palau & Palau & \\
\hline Panama & & \\
\hline Papua New Guinea & Papua New Guinea & \\
\hline Paraguay & & \\
\hline People's Republic of China & & \\
\hline Peru & & \\
\hline Philippines & & \\
\hline Pitcairn & & \\
\hline Qatar & & \\
\hline Russian Federation & & \\
\hline Rwanda & Rwanda & Rwanda \\
\hline Samoa & Samoa & Samoa \\
\hline Santa Helena & & \\
\hline São Tomé and Príncipe & Sao Tome and Principe & Sao Tome and Principe \\
\hline Saudi Arabia & & \\
\hline Senegal & Senegal & Senegal \\
\hline Seychelles & Seychellen & \\
\hline Sierra Leone & Sierra Leone & Sierra Leone \\
\hline Solomon Islands & Solomon Islands & Solomon Islands \\
\hline Somalia & Somalia & Somalia \\
\hline South Africa & South Africa (EU RSA FTA) & \\
\hline South Georgia and South Sandwich Is & & \\
\hline Sri Lanka & & \\
\hline St Kitts and Nevis & St. Kitts and Nevis & \\
\hline St Lucia & St. Lucia & \\
\hline St Pierre and Miquelon & & \\
\hline St Vincent and Northern Grenadines & St. Vincent and Grenadines & \\
\hline Sudan & Sudan & Sudan \\
\hline Suriname & Suriname & \\
\hline Swaziland & Swaziland & \\
\hline Syrian Arab Republic & & \\
\hline Tajikistan & & \\
\hline Tanzania & Tanzania & Tanzania \\
\hline Thailand & & \\
\hline Togo & Togo & Togo \\
\hline Tokelau Islands & & \\
\hline Tonga & Tonga & \\
\hline Trinidad and Tobago & Trinidad and Tobago & \\
\hline Tunisia & & \\
\hline Turkmenistan & & \\
\hline Turks and Caicos Islands & & \\
\hline Tuvalu & Tuvalu & Tuvalu \\
\hline Uganda & Uganda & Uganda \\
\hline Ukraine & & \\
\hline United Arab Emirates & & \\
\hline United States Minor outlying islands & & \\
\hline
\end{tabular}




\begin{tabular}{|l|l|l|}
\hline Uruguay & & \\
\hline Uzbekistan & & \\
\hline Vanuatu & Vanuatu & Vanuatu \\
\hline Venezuela & & \\
\hline Viet Nam & & \\
\hline Virgin Islands (British) & & \\
\hline Virgin Islands (USA) & & \\
\hline Wallis and Futuna & & \\
\hline Yemen & & Yemen \\
\hline Zambia & Zambia & Zambia \\
\hline Zimbabwe & Zimbabwe & \\
\hline
\end{tabular}




\section{Appendix 2 EU market shares of country groups: LDC, Non-ACP LDC and ACP}

\begin{tabular}{|c|c|c|c|c|}
\hline Marktaandeel in EU 2000 (\%) & LDC & Non-ACP LDC & ACP & Overlap LDC-ACP/LDC (\%) \\
\hline 01 - Live animals & 0,56 & 0,002 & 1,82 & 99,67 \\
\hline 02 - Meat and edible meat offal & 0,004 & 0,00 & 3,81 & 100 \\
\hline 03 - Fish and crustaceans, molluscs and ot & 8,5 & 1,96 & 11,22 & 76,9 \\
\hline 04 - Dairy produce; birds' eggs; natural ho & 0,01 & 0,00 & 0,15 & 100 \\
\hline 05 - Products of animal origin not elsewher & 0,33 & 0,03 & 0,83 & 91,5 \\
\hline 06 - Live trees and other plants; bulbs, root & 3,79 & 0,02 & 23,61 & 99,59 \\
\hline 07 - Edible vegetables and certain roots an & 2,39 & 0,37 & 8,58 & 84,34 \\
\hline 08 - Edible fruit and nuts; peel of citrus frui & 0,83 & 0,02 & 8,60 & 97,49 \\
\hline 09 - Coffee, tea, mate and spices & 11,58 & 0,23 & 22,77 & 98,03 \\
\hline 10 - Cereals & 0,44 & 0,002 & 2,98 & 99,56 \\
\hline 11 - Products of the milling industry; malt; & 0,10 & 0 & 0,62 & 100 \\
\hline 12 - Oil seeds and oleaginous fruits; miscell & 1,50 & 0,03 & 2,28 & 98,24 \\
\hline 13 - Lacs; gums, resins and other vegetabl & 7,67 & 0,10 & 9,31 & 98,7 \\
\hline 14 - Vegetable plaiting materials; vegetable & 2,55 & 0,02 & 4,29 & 99,31 \\
\hline 15 - Animal or vegetable fats and oils and $t$ & 3,82 & 0,002 & 10,33 & 99,95 \\
\hline 16 - Preparations of meat, fish or crustacea & 2,30 & 0,63 & 15,04 & 72,48 \\
\hline 17 - Sugars and sugar confectionery & 4,56 & 0,18 & 56,25 & 95,97 \\
\hline 18 - Cocoa and cocoa preparations & 1,48 & 0,00 & 67,76 & 100 \\
\hline 19 - Preparations of cereals, flour, starch o & 0,03 & 0,003 & 0,50 & 89,18 \\
\hline 20 - Preparations of vegetables, fruit, nuts & 0,16 & 0,01 & 3,18 & 91,43 \\
\hline 21 - Miscellaneous edible preparations & 0,05 & 0,005 & 3,31 & 89,39 \\
\hline 22 - Beverages, spirits and vinegar & 0,03 & 0,004 & 9,63 & 83,68 \\
\hline 23 - Residues and waste from the food ind & 0,58 & 0,00 & 1,04 & 100 \\
\hline 24 - Tobacco and manufactured tobacco su & 7,72 & 0,21 & 17,69 & 97,32 \\
\hline 29 - Organic chemicals & 0,07 & 0,0005 & 0,48 & 99,35 \\
\hline 35 - Albuminous substances; modified starc & 0,13 & 0,0007 & 0,13 & 99,49 \\
\hline 38 - Miscellaneous chemical products & 0,01 & 0,001 & 0,11 & 88,98 \\
\hline 56 - Wadding, felt and nonwovens; special & 0,32 & 0,06 & 0,30 & 80,79 \\
\hline 64 - Footwear, gaiters and the like; parts o & 1,21 & 1,12 & 0,29 & 7,21 \\
\hline 87 - Vehicles other than railway or tramwa & 0,16 & 0,02 & 0,16 & 85,25 \\
\hline
\end{tabular}

\begin{tabular}{l|c|c|c|c}
\hline 25 - Salt; sulphur; earths and stone; plastering mat & 0,93 & 0,0002 & 1,82 & $\mathbf{9 9 , 9 8}$ \\
26 - Ores, slag and ash & 6,24 & 0,001 & 6,99 & $\mathbf{9 9 , 9 8}$ \\
27 - Mineral fuels, mineral oils and products of their & 0,88 & 0,02 & 4,67 & $\mathbf{9 7 , 7 3}$ \\
40 - Rubber and articles thereof & 0,15 & 0,02 & 1,76 & $\mathbf{8 6 , 6 7}$ \\
44 - Wood and articles of wood; wood charcoal & 1,21 & 0,25 & 7,13 & $\mathbf{7 9 , 3 4}$ \\
51 - Wool, fine and coarse animal hair; yarn and fab & 1,4 & 1,39 & 0,05 & $\mathbf{0 , 7 1}$ \\
52 - Cotton & 5,37 & 0,03 & 8,98 & $\mathbf{9 9 , 4 4}$ \\
55 - Man-made staple fibres & 0,14 & 0,03 & 0,37 & $\mathbf{7 8 , 5 7}$ \\
61 - Articles of apparel and clothing accessories, kni & 9,1 & 8,34 & 3,44 & $\mathbf{8 , 3 5}$ \\
62 - Articles of apparel and clothing accessories, no & 5,43 & 5,06 & 1,18 & $\mathbf{6 , 8 1}$ \\
63 - Other made up textile articles; sets; worn clothi & 1,51 & 1,45 & 0,22 & $\mathbf{3 , 9 7}$ \\
71 - Natural or cultured pearls, precious or semi-pre & 4,29 & 0,02 & 4,87 & $\mathbf{9 9 , 5 3}$ \\
72 - Iron and steel & 0,02 & 0,004 & 1,1 & $\mathbf{8 0}$ \\
73 - Articles of iron or steel & 0,02 & 0,004 & 0,04 & $\mathbf{8 0}$ \\
74 - Copper and articles thereof & 0,32 & 0,01 & 0,62 & $\mathbf{9 6 , 8 8}$ \\
76 - Aluminium and articles thereof & 0,15 & 0,003 & 2,35 & $\mathbf{9 8}$ \\
81 - Other base metals; cermets; articles thereof & 4,34 & 0 & $\mathbf{1 0 0}$ \\
\hline
\end{tabular}




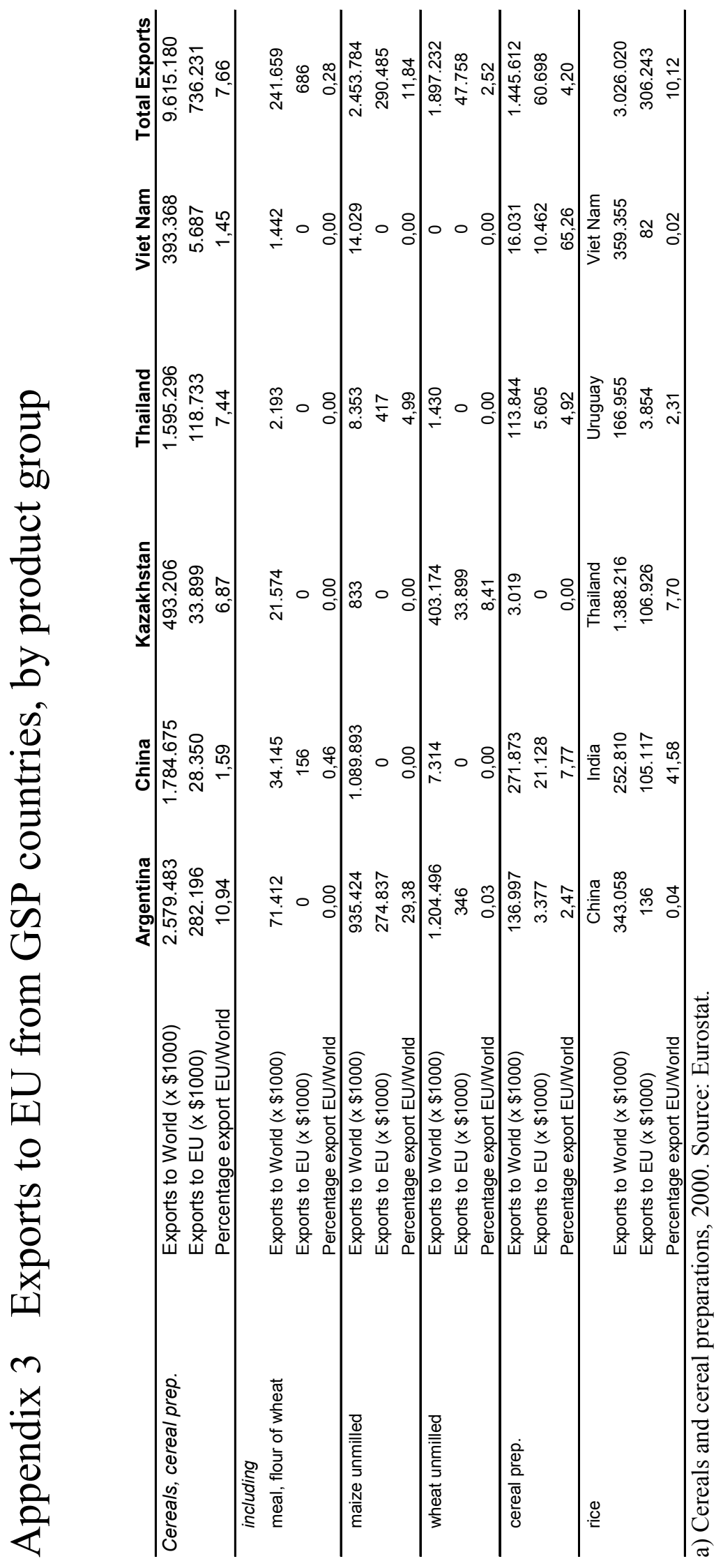




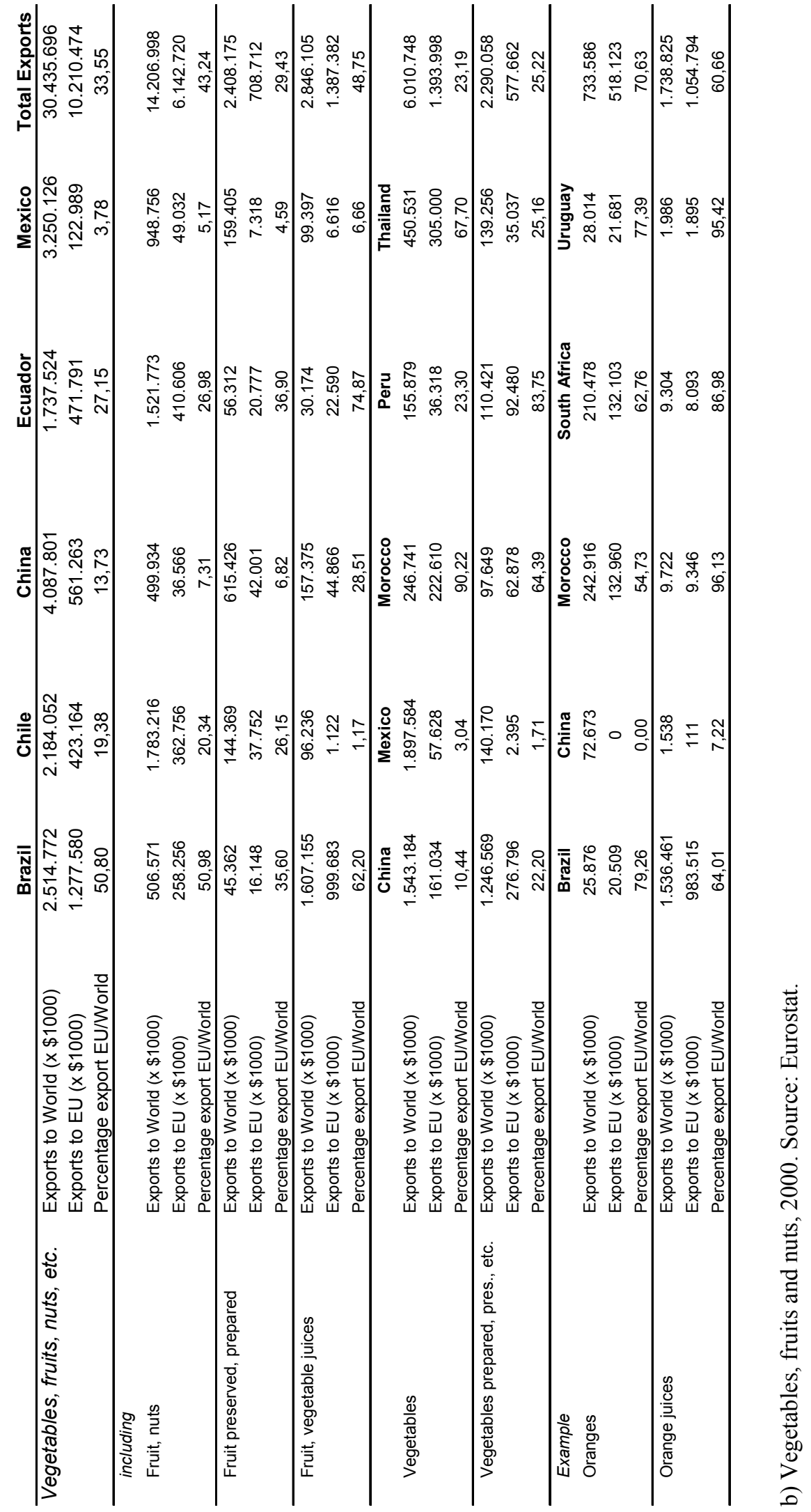




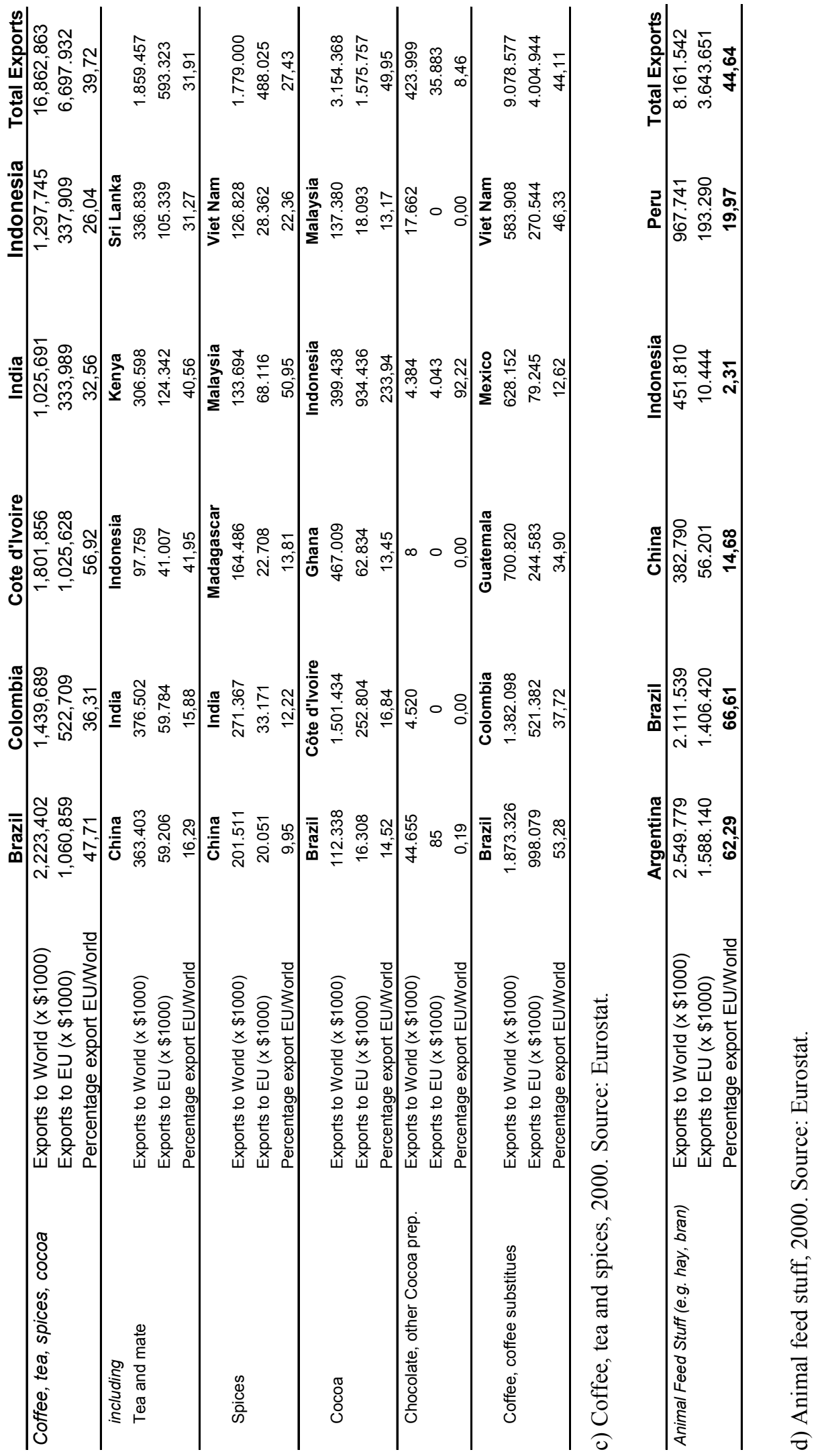




\section{Appendix $4 \quad$ Analytics of trade preferences}

Figure A4.1 provides a graphical presentation of the effects for the three countries involved and the world market equilibrium, taken from Ianchovichina et al. (2000). It shows the general case where a developed country grants a discriminatory tariff preference to one foreign supplier, at the benefit of producers in the beneficiary developing country $S$ and consumers in the importing country, and at the expense of producers in another developing country $D$ that were suppliers before the granting of the selective preference. For simplicity of presentation, the traded product is not produced in the importing country and not consumed in the other countries - say, it is an off-season horticultural product. ${ }^{1}$

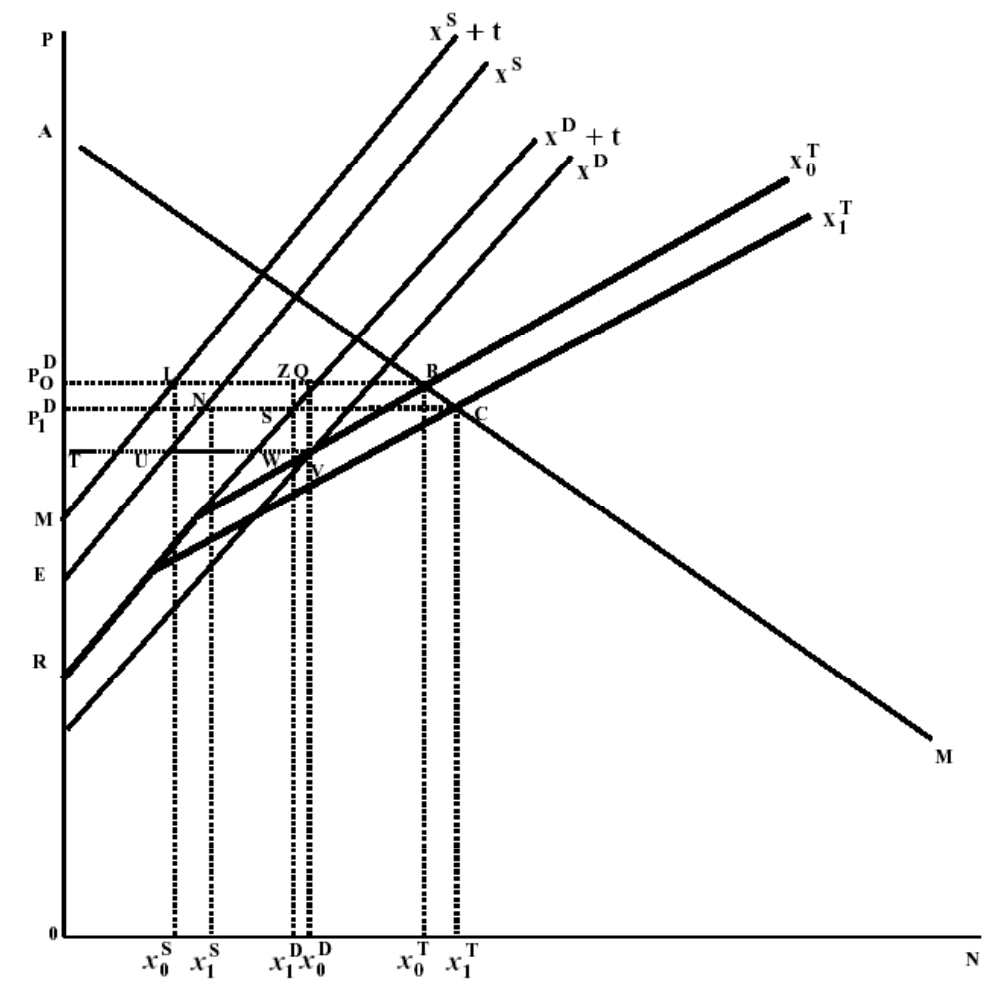

Figure A4.1 World supply and demand under preferential trade

\footnotetext{
${ }^{1}$ See Bora et al. (2002) for a more extensive graphical presentation of a partial equilibrium analysis incorporating three countries and one product. They loosen up some important assumptions underlying figure A4.1: one is that product from different origin are perfect substitutes (i.e. completely exchangeable); another is that trade is not governed by a fixed world price.
} 
At the initial market equilibrium $\mathrm{B}$, all products $\left(\mathrm{X}_{0} \mathrm{~T}\right.$ is the sum of the sum of the individual export supply curves $\mathrm{Xs}+\mathrm{t}$ and $\mathrm{Xd}+\mathrm{t}$ ) enter the importing country under tariff $\mathrm{t}$. The tariff is an ad valorem tariff, which raises the price by equal percentage at all prices, hence the constant difference between the tariff-inclusive supply curves $(\mathrm{X}+\mathrm{t})$ and tariffexclusive supply curves $(\mathrm{X})$. Import demand $\mathrm{M}$ responds to price as normally, and is satisfied when it is met by export supply at price $\mathrm{P}_{0} \mathrm{~d}$. ${ }^{1}$ Countries $\mathrm{S}$ and $\mathrm{D}$ divide the import market along their respective favoured combinations of price and supply. As $\mathrm{S}$ is granted zero-duty access $(t=0)$ and $\mathrm{D}$ is not, the latter loses market share even in an expanding import market. Changes in the terms trade coordinate the shift; as $\mathrm{S}$ no longer pays tariff duties it receives a higher price than before and expands supply, D's prices are still at tariffinclusive height. ${ }^{2}$ Reduced average price expand import demand until equilibrium is met at C. In the importing country, consumers gain from the price decrease and displaced domestic producers lose-the import demand curve only reveals the net effect, which is positivewhile public finance will have to cope with the drop in tariff $(\operatorname{tax})$ revenues.

\footnotetext{
${ }^{1}$ In the discussion on trade preferences under protective regime, the effects are discussed in the setting of an intervention price fixed above world market price.

${ }^{2}$ The assumption of upward-sloping export supply curves implies that the volume of imports of country has substantial effects on the total volume of export supply of the exporting countries. This may well be true for the beneficiary country, which, for political economics reasons will in general be a small exporter. But in the 3-country partial setting, the third country may as well be a large exporter. As Bora et al. (2002) show, in case of a flat supply curve terms of trade effects are ruled out.
} 